\title{
Phylogenetic Diversity in the Core Group of Peziza Inferred from ITS Sequences and Morphology
}

\section{Citation}

Hansen, Karen, Thomas Laessoe, and Donald H. Pfister. 2002. Phylogenetic diversity in the core group of Peziza inferred from ITS sequences and morphology. Mycological Research 106, no. 8 : 879-902.

\section{Published Version}

http://dx.doi.org/10.1017/S0953756202006287

\section{Permanent link}

http://nrs.harvard.edu/urn-3:HUL.InstRepos:3153301

\section{Terms of Use}

This article was downloaded from Harvard University's DASH repository, and is made available under the terms and conditions applicable to Other Posted Material, as set forth at http:// nrs.harvard.edu/urn-3:HUL.InstRepos:dash.current.terms-of-use\#LAA

\section{Share Your Story}

The Harvard community has made this article openly available.

Please share how this access benefits you. Submit a story.

\section{Accessibility}




\title{
Phylogenetic diversity in the core group of Peziza inferred from ITS sequences and morphology
}

\author{
Karen HANSEN ${ }^{1}$, Thomas L/ESSØE ${ }^{2}$ and Donald H. PFISTER ${ }^{1}$ \\ ${ }^{1}$ Harvard University Herbaria, Cambridge, Massachusetts, MA 02138, USA. \\ ${ }^{2}$ Department of Mycology, University of Copenhagen, Øster Farimagsgade 2 D, DK-1353 Copenhagen K, Denmark. \\ E-mail:khansen@oeb.harvard.edu \\ Received 23 January 2002; accepted 30 May 2002.
}

\begin{abstract}
Species delimitation within the core group of Peziza is highly controversial. The group, typified by $P$. vesiculosa, is morphologically coherent and in previous analyses of LSU rDNA sequences it formed a highly supported clade. Phylogenetic diversity and species limits were investigated within the group using sequences from the complete ITS region (ITS1-5.8S-ITS2). Eighty-three specimens were selected for molecular study from a larger sample of material studied morphologically to explore the intra- and interspecific variation of each putative species. The sister group taxon, $P$. ampelina was used as the outgroup and two specimens of $P$. subcitrina were additionally included. Seven independent lineages of rDNA were identified (I-VII), each representing one to several species. These lineages form two larger clades, A (II, and I or III) and B (IV-VII), supported by macromorphology: small (generally $<2 \mathrm{~cm}$ ), shallowly cup- to disc-shaped apothecia (A) and large (up to $15 \mathrm{~cm}$ ), deeply cup-shaped to expanded apothecia (B). The overall exciple structure (a stratified or non-stratified medullary layer) and to some degree spore surface relief, likewise support the groupings. Clade A contains taxa with smooth or nearly smooth spores (except for P. lohjaënsis), while clade B contains taxa with a range of spore ornamentations, from smooth, finely warty to distinctly warty, and spiny. The position of groups I ( $P$. vesiculosa and P. ammophila) and III (P. lohjaënsis) are uncertain, and these taxa also deviate morphologically from the other clade A members. The following species are recognized based on morphology and ITS rDNA analyses: $P$. ammophila and $P$. vesiculosa $(\mathrm{I}) ; P$. alcis, $P$. ampliata, $P$. domiciliana, $P$. fimeti, $P$. nivalis, and a number of putative species or intraspecific entities (II); P. lohjaënsis (III); $P$. sp. c (IV); $P$. arvernensis $(\mathrm{V})$; P. echinispora and $P$. sp. d (VI); and P. varia (VII). The nomenclature of these species is analyzed and taxa are typified as necessary. Based on ITS and morphology, we found no justification for recognizing more than one species in the ' $P$. varia complex', including 27 specimens that have been referred to under the names $P$. cerea, $P$. micropus and $P$. repanda, from an array of substrates and different geographical areas. Morphological characters previously used to delimit species within this complex, such as colour variation of the apothecia, presence or absence of a stipe, stratified or non-stratified medullary exciple (or thickness of the excipular layers), cell types in the outermost exciple and moniliform $v$ f filiform paraphyses were not correlated with the subgroups supported by ITS analyses and appeared to be plastic. Therefore, $P$. cerea and $P$. micropus are placed in synonymy with $P$. varia. The name $P$. repanda is rejected. Levels of sequence divergence were low within group II, comprising 33 small apothecial specimens. Twelve fine-scale lineages were identified, but the analyses did not resolve relationships among these. P. granulosa sensu Boudier is considered a synonym of $P$. fimeti. These have previously been distinguished mainly by occurrence on various soil types, including burnt soil and soil mixed with sawdust or woodchips $v s$ on dung. The substrate and habitat have been much emphasized in the taxonomy of Peziza, but the results obtained here indicate that populations on a diverse array of substrates may be closely related, or indeed, conspecific.
\end{abstract}

\section{INTRODUCTION}

Molecular phylogenetic studies (Norman \& Egger 1996, 1999, Hansen, Læssøe \& Pfister 2001) have shown that the genus Peziza Fr. 1822 is not monophyletic. Our previous results (Hansen et al. 2001), based on phylogenetic analyses of partial LSU rDNA sequences, suggest that Peziza is composed of at least six distinct lineages, most of which include other genera of the Pezizaceae. It is evident from these studies that, to reflect the phylogeny, Peziza must either be subdivided into several genera or a very wide generic concept must be employed. Peziza is estimated to comprise 80 species according to Hawksworth et al. (1995). No monographic treatment of the genus has ever been undertaken, although a number of subgenera and sections 
have been proposed; only a few previous attempts have been made to provide a coherent system (e.g. Donadini 1977, 1978). The group treated here (group IVa, in Hansen et al. 2001) includes the type species of Peziza, $P$. vesiculosa, and thus must serve as the core for a future recircumscription of Peziza. The clade was strongly supported in parsimony analyses of LSU rDNA sequences (bootstrap 91\%). Furthermore, the presence of a distinct amyloid ring zone at the apex of the asci is a synapomorphy (shared derived character) for the clade and its sister group, IVb (Hansen et al. 2001). It includes many common taxa characterized by mostly yellowish brown, disc- to cup-shaped apothecia, finely warted or smooth, eguttulate spores and simple, hyaline or pale yellowish paraphyses. Habitats comprise undisturbed and disturbed substrates, including rich soil mixed with litter, woody debris or mortar, plaster, brick walls, lime, burnt ground, highly decayed trunks, twigs, wood-chips, sawdust, manured substrate and dung. The species are primarily found in temperate and arctic-alpine areas. All investigated species produce Oedocephalum anamorphs (reported for P. ammophila, $P$. ampliata, P. echinispora, $P$. varia and $P$. vesiculosa) and germinate and grow easily on artificial media (e.g. Berthet 1964a, 1964b, Webster, Rifai \& Samy ElAbyad 1964, Paden 1973). Based on this and the habitats, we consider this group of Peziza species most likely to be saprotrophic. With a few exceptions the group is equivalent to Boudier's $(1885,1907)$ concept of the genus Aleuria (Fr.) Gillet 1879 non Fuckel 1870, defined primarily by eguttulate ellipsoid spores. While the delimitation of the group seems clear-cut, species limits are highly controversial, and the number of species recognized varies. Furthermore, the nomenclatural situation is unstable. Most type specimens or original material has been lost or never kept, and where material does exists it is of limited value since distinguishing ephemeral characters are not preserved. There are many taxonomically problematic species, because of morphological uniformity. Molecular divergence based on nLSU rDNA (Hansen et al. 2001) is also low within the group. Many names have been referred to the core group of Peziza; some of that are obvious synonyms while others are difficult or impossible to interpret. The group has never been revised, but most keys to Peziza sensu lato include the species names discussed in this paper (e.g. Le Gal 1941, Moser 1963, Romagnesi 1978, Hohmeyer 1986, Dissing 2000, Spooner 2001). Seaver (1928), Maas Geesteranus (1967), Rifai (1968), and Dennis (1981) give descriptions of taxa as well as keys. Several apparent species complexes occur within the group. Rifai (1968) pointed out the ' $P$. repanda-varia-micropus-cerea complex' (here referred to as the ' $P$. varia complex'), for species with large apothecia and ellipsoid, smooth, small ( $c a 15 \mu \mathrm{m}$ long) and eguttulate spores. Seaver (1928) only recognized one species within this complex, $P$. repanda, while others have accepted three or four species (e.g. Boudier 1905-10, Svrček 1970, Dennis 1981, Dissing 2000,
Spooner 2001). The most detailed study within this complex is by Svrček (1970), who also included species with finely warted spores and smaller apothecia. He recognized the following species: $P$. ampliata, $P$. crassipes, $P$. cerea, $P$. micropus, $P$. varia and $P$. arvernensis. His study provided a key and updated the nomenclature, although he did not resolve whether $P$. repanda was a synonym of $P$. micropus or a separate species. Another complex centres around fimicolous species and small species on soil, with the following associated names: $P$. alcis, $P$. bovina, $P$. fimeti, $P$. granulosa auct., $P$. sepiatra and $P$. nivalis. Furthermore, there has been considerable confusion over the naming of the snow bank species, $P$. nivalis and others in the same habitat (Pfister 1992), such as $P$. ninguis, $P$. fortoulii, and $P$. phaeotheca that have been treated in several papers (e.g. Donadini 1977, 1979, 1980a) and keys (e.g. Hohmeyer 1986, Spooner 2001).

The core group of Peziza includes some of the most difficult taxonomic and nomenclatural problems in the Pezizales. In this study, using molecular phylogenetic methods, we aim to evaluate some of the morphological characters and substrate specificities previously used to separate species within this group. We have examined the intra- and interspecific phylogenetic diversity of the group, using sequences of ITS1-5.8S-ITS2 rDNA (ITS) from a broad selection of samples. We have collected and used fresh specimens whenever possible. The primary goals were to delimit species within the core group of Peziza using sequence analyses and morphology, and to provide insight into phylogenetic relationships among the species.

\section{MATERIALS AND METHODS}

\section{Specimens examined}

Morphological studies used type and other material from C, FH, G, H, K, L, PC, PRM, TUR and TURA and from the private herbaria of Roy Kristiansen, Trond Schumacher (to be placed in O), Nancy Weber (to be placed in OSC) and Wulfard Winterhoff. The greater part, however, were collected as part of this study and are deposited in C. All studied specimens have been annotated and a complete list of specimens is available on request from K. H., the British Mycological Society Library at Kew (K), and Farlow Library of Cryptogamic Botany (FH). Morphological studies aided the selection of specimens for subsequent molecular studies. Eighty-three collections of the core group of Peziza were selected (Table 1) to cover the range of morphological characters and substrates. Collections from across geographical ranges were included whenever possible. Peziza ampelina, a representative for the suggested sister group to the ingroup (group IVb in Hansen et al. 2001), was used as the outgroup. In addition, two collections of $P$. subcitrina (a group IVb member in Hansen et al. 2001) were included. 
Table 1. Peziza collections used in the molecular phylogenetic study.

\begin{tabular}{|c|c|c|c|c|}
\hline Species $^{\mathrm{a}}$ & $\begin{array}{l}\text { Collection } \\
\text { number }\end{array}$ & $\begin{array}{l}\text { Geographic origin } \\
\text { and substrate }\end{array}$ & Year and collector & $\begin{array}{l}\text { GenBank } \\
\text { accession no }\end{array}$ \\
\hline P. alcis (1) & s.n. (H, holotype) & Finland. Dung of elk (Alces) & 1977, H. Harmaja & AF491612 \\
\hline P. alcis (2) & KH 00.019 (C) & Norway. Dung of elk (Alces) & 2000, H. Dissing & AF491611 \\
\hline P. alcis (3) & TL-5529 (C) & Sweden. Dung of elk (Alces) & 1999, T. Læssøe & AF491610 \\
\hline P. ammophila (1) & KH-98-88 (C) & $\begin{array}{l}\text { Denmark. Near Ammophila in coastal } \\
\text { sand dunes }\end{array}$ & 1988, K. Hansen & AF491622 ${ }^{\mathrm{b}}$ \\
\hline P. ammophila (2) & NSW 7081 (OSC) & USA, OR. Sand dunes near vegetation & 1993, F. Camacho & AF491621 \\
\hline P. ampelina & KH $00.011(\mathrm{C})$ & Denmark. Bare, clayey soil & 1994, C. Lange & AF491629 \\
\hline P. ampliata (1) & JHC 92-386 (C) & Denmark. Large rotten Fagus trunk & 1992, J. Heilmann-Clausen & AF491590 \\
\hline P. ampliata (2) & KH-97-81 (C) & Denmark. Bark of indet. deciduous tree & 1997, J. H. Petersen & AF491591 \\
\hline P. ampliata (3) & KH-97-130 (C) & Denmark. Soil, wood-chips and debris & 1997, C. Lange & AF491589 \\
\hline P. ampliata (4) & KH 00.027 (C) & Denmark. Large Populus trunk & 2000, K. Hansen & AF491588 \\
\hline P. ampliata (5) & KH 00.004 (C) & Denmark. Lime & 2000, C. Lange & AF491592 \\
\hline P. arvernensis (1) & KH-98-08 (C) & Denmark. Soil, among Fagus leaves & 1998, A. Storgaard & AF491584 \\
\hline P. arvernensis (2) & KH-98-12 (C) & $\begin{array}{l}\text { Denmark. Edge of pile of sawdust, } \\
\text { wood-chips and small twigs }\end{array}$ & 1998, B. Klug-Andersen & AF491582 \\
\hline P. arvernensis (3) & KS-95-13 (C) & Denmark. Soil, leaves of Fagus and sawdust & 1995, K. Hansen, S. K. Sandal & AF491585 \\
\hline P. arvernensis (4) & KS-95-09 (C) & Denmark. Soil among leaves along road & 1995, K. Hansen, S. K. Sandal & AF491583 \\
\hline P. arvernensis (5) & L 9985 (L) & $\begin{array}{l}\text { Netherlands. Wood remnants, cut Fagus } \\
\text { branches along road }\end{array}$ & 1986, H. van der Aa & AF491581 \\
\hline P. arvernensis (6) & KS-94-28A (C) & $\begin{array}{l}\text { Denmark. Disturbed soil, heaps of lime } \\
\text { and stone }\end{array}$ & 1994, K. Hansen, S. K. Sandal & $\mathrm{AF} 491578^{\mathrm{b}}$ \\
\hline P. arvernensis (7) & KS-94-145 (C) & $\begin{array}{l}\text { Denmark. Soil and leaves of Fagus, } \\
\text { in ditch }\end{array}$ & 1994, K. Hansen, S. K. Sandal & AF491577 \\
\hline P. arvernensis (8) & s.n. (FH) & USA, CA. Leaf duff, with Quercus & 1998, B. Niell & AF491579 \\
\hline P. arvernensis (9) & NSW 6714 (OSC) & USA, OR. Edge of burned slash pile & 1992, N. S. Weber & AF491580 \\
\hline P. domiciliana & C $52152(\mathrm{C})$ & Denmark. Mortar on soil in forest & 1989, P. M. Petersen & AF491614 b \\
\hline P. echinispora (1) & $\begin{array}{l}\text { Jukka Vauras } \\
\text { 9110F (TURA) }\end{array}$ & Finland. Fire site & 1994, J. Vauras & AF491575 \\
\hline P. echinispora (2) & NSW 6763 (OSC) & USA, OR. Burnt ground and debris & 1992, N. S. Weber, G. Coleman & AF491574 \\
\hline P. echinispora (3) & TL-6404 (C) & Denmark. Burnt ground & 2000, T. Læssøe & AF491573 \\
\hline P. fimeti (1) & HK 99.483 (C) & Russia, Sakha. Dung of horse & 1999, U. Peintner & AF491597 \\
\hline P. fimeti (2) & HK $99.113(\mathrm{C})$ & Russia, Sakha. Dung of cow & 1999, H. Knudsen & AF491596 \\
\hline P. fimeti (3) & TL-5449 (C) & $\begin{array}{l}\text { Denmark. Dung of cow in calcareous } \\
\text { grassland }\end{array}$ & 1999, T. Laessøe & AF491598 \\
\hline P. fimeti (4) & NSW 6266 (OSC) & USA, NM. Aged cow manure & 1990, N. S. Weber & AF491595 \\
\hline P. fimeti (5) & HK $2000.69(\mathrm{C})$ & Greenland. Dung of reindeer (Rangifer) & 2000, K. Kalamees & AF491594 \\
\hline $\begin{array}{l}P . \text { fimeti }(6) \\
\text { as } P \text {. granulosa }\end{array}$ & KH-98-26 (C) & $\begin{array}{l}\text { Denmark. Soil/sawdust mixture } \\
\text { under Fagus }\end{array}$ & 1998, H. Knudsen & $\mathrm{AF} 491600^{\mathrm{b}}$ \\
\hline $\begin{array}{l}\text { P. fimeti }(7) \\
\text { as P. granulosa }\end{array}$ & TL-4935 (C) & $\begin{array}{l}\text { Denmark. Soil mixed with wood-chips/ } \\
\text { sawdust }\end{array}$ & 1998, T. Laessøe & AF491599 \\
\hline $\begin{array}{l}\text { P. fimeti }(8) \\
\text { as P. granulosa }\end{array}$ & KS-94-12 (C) & Denmark. Fire site & 1994, K. Hansen, S. K. Sandal & AF491601 \\
\hline $\begin{array}{l}\text { P. fimeti (9) } \\
\text { as P. granulosa }\end{array}$ & HK $99.362(\mathrm{C})$ & $\begin{array}{l}\text { Russia, Sakha. Sandy, clayey soil on } \\
\text { slope from steppe to river }\end{array}$ & 1999, U. Peintner & AF491593 \\
\hline $\begin{array}{l}\text { P. fimeti }(10) \\
\text { as } P \text {. sepiatra }\end{array}$ & TL-5368 (C) & England. Fire site & 1999, T. Laessøe, J. H. Petersen & AF491604 \\
\hline $\begin{array}{l}P . \text { fimeti }(11) \\
\text { as } P \text {. crassipes }\end{array}$ & C $52151(\mathrm{C})$ & $\begin{array}{l}\text { Denmark. Clayey soil with hardwood } \\
\text { sawdust }\end{array}$ & 1983, S. A. Elborne, H. Knudsen & AF491606 \\
\hline $\begin{array}{l}\text { P. fimeti }(12) \\
\text { as } P \text {. granulosa }\end{array}$ & KH 00.012 (C) & Denmark. Bare, very moist, rich soil & 1994, K. Hansen, S. K. Sandal & AF491605 \\
\hline P. lohjaënsis & s.n. (H, holotype) & $\begin{array}{l}\text { Finland. Bare mull, in rich wood on } \\
\text { somewhat calcareous ground }\end{array}$ & 1982, H. Harmaja & AF491576 \\
\hline P. nivalis (1) & KH-97-44 (C) & $\begin{array}{l}\text { USA, CA. Soil and decaying grasses, } \\
\text { at edge of snow bank, burnt ground }\end{array}$ & 1997, K. Hansen & AF491620 \\
\hline P. nivalis (2) & NSW 6740 (OSC) & $\begin{array}{l}\text { USA, OR. Soil and charred bits of } \\
\text { vegetation near melting snow, burnt ground }\end{array}$ & 1992, N. S. Weber et al. & AF491619 \\
\hline P. subcitrina (1) & KH-97-133 (C) & Denmark. Bare soil along ditch & 1997, K. Hansen, C. Lange & AF491628 \\
\hline P. subcitrina (2) & KH 00.023 (C) & $\begin{array}{l}\text { Denmark. Soil and sawdust, along } \\
\text { forest road }\end{array}$ & 2000, K. Hansen, S. Landvik & AF491627 b \\
\hline $\begin{array}{l}P . \text { varia }(1) \\
\text { as } P \text {. cerea }\end{array}$ & KH-97-54 (C) & Denmark. Plaster in basement & 1997, J. H. Petersen & AF491559 \\
\hline $\begin{array}{l}P . \text { varia }(2) \\
\text { as } P . \text { cerea }\end{array}$ & KH-97-01 (C) & $\begin{array}{l}\text { USA, MA. On wet carpet in basement and } \\
\text { directly on plaster }\end{array}$ & 1997, K. Hansen & AF491555 \\
\hline $\begin{array}{l}P \text {. varia }(3) \\
\text { as } P \text {. cf. repanda }\end{array}$ & $\begin{array}{l}\text { Jukka Vauras } \\
1271 \mathrm{~F} \text { (TUR) }\end{array}$ & $\begin{array}{l}\text { Finland. Basement, near concrete wall of } \\
\text { coarse sand }\end{array}$ & 1982, J. Vauras & $\mathrm{AF} 491570^{\mathrm{b}}$ \\
\hline
\end{tabular}


Table 1. (cont.)

\begin{tabular}{|c|c|c|c|c|}
\hline Species $^{\mathrm{a}}$ & $\begin{array}{l}\text { Collection } \\
\text { number }\end{array}$ & $\begin{array}{l}\text { Geographic origin } \\
\text { and substrate }\end{array}$ & Year and collector & $\begin{array}{l}\text { GenBank } \\
\text { accession no. }\end{array}$ \\
\hline P. varia (4) & KH 00.003 (C) & $\begin{array}{l}\text { Denmark. Hardwood sawdust and } \\
\text { on rich soil }\end{array}$ & 2000, H. Knudsen, M. Sasa & AF491569 \\
\hline P. varia (5) & KH $00.022(\mathrm{C})$ & $\begin{array}{l}\text { Denmark. Sawdust from Larix and } \\
\text { on rich soil }\end{array}$ & 1999, H. Knudsen & AF491568 \\
\hline $\begin{array}{l}\text { P. varia }(6) \\
\text { as } P \text {. cerea }\end{array}$ & KH 00.033 (C) & $\begin{array}{l}\text { Denmark. Gravel and sand, in driveway } \\
\text { to a house }\end{array}$ & 2000, H. H. Schierup & AF491567 \\
\hline $\begin{array}{l}\text { P. varia }(7) \\
\text { as } P \text {. cf. micropus }\end{array}$ & KH $00.028(\mathrm{C})$ & Denmark. Large Populus trunk & 2000, K. Hansen & AF491562 \\
\hline P. varia (8) & KH-97-02 (C) & USA, MA. Decorticated indet. hardwood & 1997, D. S. Hibbett & AF491561 \\
\hline $\begin{array}{l}P . \text { varia }(9) \\
\text { as } P \text {. cf. repanda }\end{array}$ & NSW 6504 (OSC) & $\begin{array}{l}\text { USA, OR. Wood, soil with woody debris } \\
\text { and sunflower fruits }\end{array}$ & 1991, N. S. Weber & AF491565 \\
\hline $\begin{array}{l}P . \text { varia }(10) \\
\text { as } P . \text { micropus }\end{array}$ & KH-98-104 (C) & Denmark. Dead standing Ulmus & 1998, J. Heilmann-Clausen & AF491566 \\
\hline P. varia $(11)$ & KH-98-38 (C) & $\begin{array}{l}\text { Denmark. Innerside of bark of large Salix } \\
\text { trunk }\end{array}$ & 1998, K. Hansen & AF491564 \\
\hline P. varia (12) & KH-98-03 (C) & Denmark. Decayed Salix trunk & 1998, K. Hansen & AF491563 \\
\hline $\begin{array}{l}P . \text { varia }(13) \\
\text { as } P \text {. cf. cerea }\end{array}$ & s.n. (TUR) & $\begin{array}{l}\text { Finland. Brick wall, where excess water } \\
\text { has penetrated the structure }\end{array}$ & 1994, S. Huhtinen & AF491560 \\
\hline $\begin{array}{l}P . \text { varia }(14) \\
\text { as } P \text {. cf. micropus }\end{array}$ & KH-97-88 (C) & Denmark. Large Fagus trunk & 1997, K. Hansen & AF491556 \\
\hline P. varia $(15)$ & KH-99-04 (C) & USA, MA. Very decayed wood & 1999, Z.-L. Yang & AF491558 \\
\hline $\begin{array}{l}P . \text { varia }(16) \\
\text { as } P . \text { cerea and } \\
P . \text { arvernensis }\end{array}$ & s.n. (TUR) & Finland. Not stated & 1978, Y. Mäkinen & AF491557 \\
\hline $\begin{array}{l}\text { P. varia }(17) \\
\text { as } P . \text { micropus }\end{array}$ & KH-97-107 (C) & Denmark. Large Fagus trunk & 1997, K. Hansen & AF491549 \\
\hline $\begin{array}{l}P . \text { varia }(18) \\
\text { as } P . \text { micropus }\end{array}$ & TL-4604 (C) & Russia, Kamchatka. Decayed Betula trunk & 1997, H. Knudsen & AF491554 \\
\hline $\begin{array}{l}P . \text { varia }(19) \\
\text { as } P . \text { micropus }\end{array}$ & KH-97-125 (C) & Denmark. Large Fagus trunk & 1997, K. Hansen et al. & AF491547 \\
\hline $\begin{array}{l}\text { P. varia }(20) \\
\text { as } P . \text { micropus }\end{array}$ & TL-4691 (C) & Russia, Kamchatka. Large Populus trunk & 1997, T. Læssøe & AF491552 \\
\hline $\begin{array}{l}\text { P. varia }(21) \\
\text { as } P . \text { micropus }\end{array}$ & JHP $00.283(\mathrm{C})$ & Denmark. Decayed Fagus trunk & 2000, T. Læssøe, J. H. Petersen & AF491548 \\
\hline $\begin{array}{l}P . \text { varia }(22) \\
\text { as } P . \text { repanda }\end{array}$ & TL-5396 (C) & England. Decayed Fagus trunk & 1999, T. Læssøe, J. H. Petersen & AF491546 \\
\hline $\begin{array}{l}\text { P. varia }(23) \\
\text { as } P \text {. repanda }\end{array}$ & s.n. (TUR) & Finland. Decayed Populus tremula trunk & 1992, L. Kosonen & AF491553 \\
\hline P. varia $(24)$ & KH-99-08 (C) & $\begin{array}{l}\text { USA, MA. Wood, at the base of live } \\
\text { but old Acer }\end{array}$ & 1999, K. Griffith & AF491550 \\
\hline P. varia $(25)$ & D-400 (C) & USA, MA. Decayed Ulmus trunk & 1999, K. Griffith et al. & AF491551 \\
\hline $\begin{array}{l}P . \text { varia }(26) \\
\text { as } P \text {. cf. micropus }\end{array}$ & KH $00.032(\mathrm{C})$ & Denmark. Bark of decayed Quercus trunk & 2000, M. Kemp & AF491545 \\
\hline $\begin{array}{l}P . \text { varia }(27) \\
\text { as } P \text {. arvernensis }\end{array}$ & HFG 82.167 (C) & Denmark. Decaying Fagus trunk & 1982, H. F. Gøtzsche & AF491544 \\
\hline P. vesiculosa (1) & JV 95.652 (C) & Denmark. Straw & 1995, S. Hansen, J. Vesterholt & AF491626 \\
\hline P. vesiculosa (2) & NSW 6124 (OSC) & USA, OR. Bales of hay & 1989, R. Crawford, J. Weber & AF491625 \\
\hline P. vesiculosa (3) & C $52150(\mathrm{C})$ & $\begin{array}{l}\text { England. Mulched beds, with Taxus } \\
\text { and Cedrus }\end{array}$ & 2000, B. M. Spooner & $\mathrm{AF} 491624^{\mathrm{b}}$ \\
\hline P. vesiculosa (4) & TL-6398 (C) & Denmark. Horse manure & 2000, T. Læssøe & AF491623 \\
\hline Peziza sp. a (1) & KH-97-99a (C) & Denmark. Almost bare calcareous soil & 1997, C. Lange & AF491617 b \\
\hline Peziza sp. a (2) & KH-97-129 (C) & $\begin{array}{l}\text { Denmark. Bare clayey soil in old } \\
\text { wheel track }\end{array}$ & 1997, C. Lange & AF491615 \\
\hline Peziza sp. a (3) & KH-97-134 (C) & Denmark. Rich soil, along forest road & 1997, K. Hansen et al. & AF491616 \\
\hline Peziza sp. b & KH-98-53 (C) & $\begin{array}{l}\text { Austria. Bare soil, under Cirsium, } \\
\text { alt. } 1800 \mathrm{~m}\end{array}$ & 1998, K. Hansen & AF491609 \\
\hline Peziza sp. c (1) & KH $00.002(\mathrm{C})$ & $\begin{array}{l}\text { Denmark. Hardwood sawdust and } \\
\text { rich soil }\end{array}$ & 2000, H. Knudsen, M. Sasa & AF491587 \\
\hline Peziza sp. c (2) & KH $00.020(\mathrm{C})$ & Denmark. Sawdust from Larix and rich soil & 1999, H. Knudsen & AF $491586^{b}$ \\
\hline Peziza sp. d (1) & NSW 6406 (OSC) & USA, OR. Soil mixed with wood chips & 1991, N. S. Weber et al. & AF491572 \\
\hline Peziza sp.d (2) & NSW 6429 (OSC) & $\begin{array}{l}\text { USA, OR. Soil among grasses at } \\
\text { edge of road }\end{array}$ & 1991, N. S. Weber & AF491571 \\
\hline Peziza sp. e (1) & HD S85.41 (C) & Svalbard. Silt with running water & 1985, H. Dissing & AF491608 \\
\hline Peziza sp. e (2) & HK 87-273 (C) & Greenland. Sandy clay among Juncus & 1987, H. Knudsen & AF491607 \\
\hline
\end{tabular}


Table 1. (cont.)

\begin{tabular}{|c|c|c|c|c|}
\hline Species ${ }^{\mathrm{a}}$ & $\begin{array}{l}\text { Collection } \\
\text { number }\end{array}$ & $\begin{array}{l}\text { Geographic origin } \\
\text { and substrate }\end{array}$ & Year and collector & $\begin{array}{l}\text { GenBank } \\
\text { accession no. }\end{array}$ \\
\hline Peziza sp. f & NSW 7213 (OSC) & USA, OR. Soil at campfire site & 1994, L. Wilson & AF491613 \\
\hline Peziza sp. g & NSW 6762 (OSC) & USA, OR. Damp, disturbed mineral soil & 1992, N. S. Weber, G. Coleman & AF491618 \\
\hline $\begin{array}{l}\text { Peziza } \mathrm{sp} . \mathrm{h} \\
\text { as } P \text {. fimeti }\end{array}$ & TAA 128087 (TAA) & Estonia. Dung of Beaver (Castor) & 1997, A. Kollom & AF491602 \\
\hline Peziza sp. i & C $52153(\mathrm{C})$ & Denmark. On dead Phragmites, by lake & 1982, S. A. Elborne, H. Knudsen & AF491603 \\
\hline
\end{tabular}

a Species determination by K. Hansen based on morphological characters and ITS rDNA.

${ }^{b}$ Sequences provided by Sara Landvik.

\section{Morphological methods}

All material was studied by light microscopy by K.H. The observations were made from fresh or dried collections. In addition, observations on fresh material by Nancy Weber (NSW collections) were made available for this study. Dried material was revived in water overnight, or for a minimum of $3 \mathrm{~h}$. Hymenial elements were studied by teasing apart a piece of hymenium with a fine needle. Structural features of the exciple were studied using vertical, median sections made by hand or cut on a freezing microtome (15-30 $\mu \mathrm{m}$ thick) (ReichertJung, Frigocut E 2800). Measurements and descriptions were made on material mounted in water, or sometimes in $2-10 \% \mathrm{KOH}$ for rehydrated dried material. Other chemicals used were Melzer's reagent, Congo red in ammonia, and Cotton blue in lactic acid. The spore surface from several fresh collections of each putative species were viewed with a Phillips scanning electron microscope (SEM) to study the variation of the ornamentation within and between putative species; ascospores were discharged onto a cover glass, airdried, placed on a stub and coated with gold-palladium alloy.

\section{Molecular techniques}

DNA was isolated from dried or fresh ascomata (stored in extraction buffer) and was extracted as outlined in Hansen, Pfister \& Hibbett (1999), except the material was not ground in liquid nitrogen, but shaken in a Fastprep $^{\text {TM }}$ FP120 Cell Disruptor (BIO 101, CA). Serial dilutions of DNA $(1: 10,1: 100,1: 1000)$ were used as template for the polymerase chain reaction (PCR). The nuclear ribosomal ITS1-5.8S-ITS2 region was amplified with the primer pair ITS4 and ITS5 (White et al. 1990). The amplifications were done in a Peltier Thermal Cycler PTC-200 using the following program: 35-40 cycles at $94{ }^{\circ} \mathrm{C}$ for $30 \mathrm{~s}, 60^{\circ}$ for $30 \mathrm{~s}$, and 72 for $1.30 \mathrm{~min}$, followed by a $14^{\circ}$ soak. PCR fragments were purified using QIAquick spin columns (1997 Qiagen). The primers ITS1, ITS4, and internal primers ITS3 and 5.8S (White et al. 1990, Hibbett et al. 1995) were used for BigDye terminator cycle sequencing (Applied Biosystems, Foster City, CA). Cycle sequencing was done in a Peltier Thermal Cycler PTC-100 (MJ Research, Watertown, MA) using the following program: 25 cycles of $30 \mathrm{~s}$ at $98^{\circ}$ and $4 \mathrm{~min}$ at $60^{\circ}$, followed by a $14^{\circ}$ soak. Sequencing reactions were purified using the DyeEx ${ }^{\mathrm{TM}}$ spin kit (2000 Qiagen). Sequencing reactions were electrophoresed and data collected on an Applied Biosystems 377 automated DNA sequencer (Perkin-Elmer/ABI). Fifteen of the collections were sequenced by Sara Landvik (Novozymes, Copenhagen) using a slightly different procedure: the DNA was extracted with the FastDNA Kit S (BIO 101) and the PCR products were cleaned with the GFX PCR, DNA and Gel Band purification Kit (Amersham Pharmacia Biotech, NJ). Sequencing reactions were electrophoresed and data collected on an ABI 3700 (Perkin-Elmer).

Three groups of specimens (IV, V and VII) possessed sequences with short homopolymere regions of 8 to 12 T's or A's in different positions, which caused sequencing problems. The majority of these sequences were obtained by use of internal primers reading in both directions. To obtain complete sequence data from six of these specimens, however, and from three other herbarium specimens $(P$. alcis $(1), P$. echinispora (1) and $P$. fimeti (4)), PCR products, generated with the use of Pfu DNA polymerase, were cloned by use of the PCR-Script ${ }^{\mathrm{TM}}$ Amp cloning kit (Stratagene Cloning Systems, La Jolla, CA) following the manufacturer's instructions.

\section{Alignment and phylogenetic analyses}

Sequences were edited and contigs assembled using Sequencher 3.0 (GeneCodes, Ann Arbor, MI) and are deposited in GenBank (Table 1). Nucleotide sequences were aligned manually in the Sequence Alignment Editor Se-Al (Rambaut 1996) with alignment gaps inserted to optimize aligned sites. Alignments are available from TreeBASE (http://phylogeny.harvard. edu/treebase) as accession nos M1221 (all taxa), M1222 (Group II separately) and M1223 (Group VII separately). The ITS rDNA contained highly divergent regions, within which only certain subsets of the taxa or populations could be aligned. Therefore, parts of the final dataset were interleaved in alternating blocks of aligned complete sequences and aligned partial sequences. Two data sets, the inclusive and exclusive datasets, were developed to explore the sensitivity of the results to inclusion or exclusion of ambiguously aligned regions. In both data sets gapped positions were 
included and treated as missing data (gap = missing coding). The ITS sequence of $P$. lohjaënsis was in preliminary analyses found to be very different from the ITS sequences of the rest of the ingroup. To examine the sensitivity of the results to the inclusion or exclusion of $P$. lohjaënsis, this species was omitted in a separate analysis of the inclusive dataset.

Based upon analyses including all collections, which identified two distinct larger clades (designated group II and VII), two additional alignments were constructed that included only collections from each clade. In this way the total number of gaps required for alignment were reduced and the possibility of inclusion of additional characters from regions that were too divergent to be aligned across all taxa were explored. In analyses of the two subset alignments, gaps were scored as missing or as characters (indel coding) following guidelines outlined in Hibbett et al. (1995). Peziza arvernensis (7) (numbers in parentheses refer to specimen codes in Table 1) was used as an outgroup for both clades, because it was the easiest to align from among the sister group taxa.

Phylogenetic analyses were performed in PAUP*4.0b8 (Swofford 1998) on an iMac $350 \mathrm{MHz}$. All characters were equally weighted and unordered. Each maximum parsimony analysis was performed in two parts based on strategies designed by Maddison, Ruvolo \& Swofford (1992) and Olmstead et al. (1993). First, 1000 heuristic searches were performed, with random taxon addition and TBR branch swapping, with MAXTREES unrestricted, keeping only up to two trees per replicate. Secondly, exhaustive swapping was performed on all of the most parsimonious trees discovered in the first part of the analysis, with MAXTREES set to 15000 . Relative robustness of individual branches was estimated by bootstrap, using 1000 replicates, with heuristic searches, 100 random addition sequences, TBR branch swapping and MAXTREES set at 100. For the two subset alignments, each of group II and VII, branch-and-bound searches were in addition conducted, which guarantees discovery of all most parsimonious trees. Under this search method some of the specimens with identical sequences in the group VII dataset, were excluded to reduce the search time.

\section{RESULTS}

\section{Alignment}

The datasets consisted of 86 ITS rDNA sequences determined in this study (Table 1). The inclusive data set included all characters. The exclusive data set omitted four divergent or particularly ambiguous regions: positions 173-308, 360-390, 757-780 and $807-825$. The ITS region varies considerably in length (Table 2), even though these taxa are considered closely related species based on LSU rDNA sequences and morphology. ITS1 was found to vary in length from
Table 2. Nucleotide length of ITS1, ITS2 and ITS1-5.8S-ITS2 (excluding gaps).

\begin{tabular}{llll}
\hline Lineage/species & ITS1 & ITS2 & Total ITS \\
\hline I/P. ammophila & $218-236$ & $182-187$ & $557-580$ \\
I/P. vesiculosa & 232 & 216 & 605 \\
II & $192-195$ & $171-176$ & $522-526$ \\
II/P. alcis & 207 & 174 & 538 \\
III/P. lohjaënsis & 203 & 176 & 536 \\
IV/P. sp. c & 231 & 176 & 564 \\
V/P. arvernensis & 221 & $176-180$ & $554-559$ \\
VI/P. echinispora & 238 & 197 & 592 \\
VI/P. sp. d & 256 & 185 & 598 \\
VII a & $223-226$ & $188-191$ & $568-574$ \\
VII b/Denmark & 235 & 210 & 597 \\
VII b/Kamchatka & 247 & 193 & 602 \\
\hline
\end{tabular}

approximately 192 to 256 bp (excluding gaps) within the core group of Peziza, and ITS2 ranged in length from approximately 171 to $216 \mathrm{bp}$. The shortest ITS1 and ITS2 were found within the group of species with small apothecia $(P$. sp. g and $P$. fimeti), while the longest ITS1 was found in $P$. sp. $\mathrm{d}$ and the longest ITS2 in $P$. vesiculosa. In general the different lengths of the ITS region correspond to the groups recovered by the phylogenetic analyses (Table 2, Figs 1-3). ITS1 and ITS2 were aligned along with the intervening $5.8 \mathrm{~S}$ rDNA (uniformly $157 \mathrm{bp}$ long) and flanking partial sequences of $18 \mathrm{~S}$ ( $c a 59 \mathrm{bp}$ ) and 25S rDNA ( $c$ a $59 \mathrm{bp}$ ). The aligned length of all sequences, including inserted gaps, was $899 \mathrm{bp}$.

\section{Phylogenetic relationships}

The number of included, variable and parsimony informative characters for each data set are given in Table 3, along with the number and length of the most parsimonious trees (MPTs) found in each analysis, consistency index $[\mathrm{CI}]$ and retention index [RI].

\section{All taxa}

The results of the different analyses, including all collections, differed slightly in bootstrap values and in degree of resolution of the strict consensus trees, but no conflicting nodes received bootstrap support above $65 \%$. The strict consensus trees of the inclusive data set (Fig. 1) and the exclusive dataset (Fig. 2) demonstrate these differences. The basal node of the ingroup topology differs under the two sets of analyses. In the strict consensus tree of the inclusive data set the ingroup root is placed along the branch leading to group I (Fig. 1), thus grouping P. lohjaënsis with group II (bootstrap 63\%). Whereas in the strict consensus tree of the exclusive data set the ingroup root is placed along the branch leading to the P. lohjaënsis lineage (Fig. 2), grouping $P$. vesiculosa and $P$. ammophila with group II (bootstrap $<50 \%$ ).

The core group of Peziza (group IVa in Hansen et al. 2001) was highly supported as monophyletic (bootstrap 
Table 3. Information of the various data sets analyzed and the most parsimonious trees found.

\begin{tabular}{|c|c|c|c|c|c|c|c|c|}
\hline \multirow[b]{2}{*}{ Data set } & \multirow[b]{2}{*}{ Matrix size } & \multicolumn{3}{|c|}{ Characters } & \multicolumn{2}{|l|}{ Trees } & \multirow[b]{2}{*}{ CI } & \multirow[b]{2}{*}{ RI } \\
\hline & & Included & Variable & Informative & Number & Length & & \\
\hline Inclusive $^{\mathrm{a}}$ & 899 & 899 & 353 & 311 & $>15000$ & 793 & 0.660 & 0.927 \\
\hline Exclusive $^{\mathrm{a}}$ & 899 & 689 & 235 & 197 & $>15000$ & 532 & 0.635 & 0.922 \\
\hline Group II $^{a}$ & 694 & 694 & 122 & 87 & 90 & 196 & 0.740 & 0.849 \\
\hline Group II $^{\mathrm{b}}$ & 709 & 698 & 134 & 101 & 108 & 216 & 0.745 & 0.857 \\
\hline Group VII ${ }^{a}$ & 766 & 766 & 97 & 56 & 156 & 117 & 0.897 & 0.958 \\
\hline Group VII ${ }^{\mathrm{b}}$ & 780 & 774 & 109 & 69 & 156 & 135 & 0.904 & 0.966 \\
\hline
\end{tabular}

a Gap $=$ missing coding.

${ }^{\mathrm{b}}$ Gap $=$ indel coding.

$99 \%$ ). Despite the large number of trees the strict consensus trees are fairly well resolved. Seven distinct rDNA lineages of species or populations were identified (groups I-VII) that were highly supported (bootstrap 89-100\%) (Figs 1-2), except for lineage $\mathrm{V}$ that only received $58 \%$ bootstrap support in the strict consensus tree of the exclusive data set (Fig. 2). In the strict consensus tree of the inclusive data set, however, lineage $\mathrm{V}$ was supported by $98 \%$ of the bootstrap replicates (Fig. 1). The single collection of P. lohjaënsis constitutes a separate lineage (group III). Excluding $P$. lohjaënsis from the analysis of the inclusive data set did not change the overall topology, except the strict consensus tree was more resolved within group II (topology not shown), and within and between the groups IV-VII (congruent with the tree derived from the exclusive data set, Fig. 2). The overall topology is congruent with the topology derived from LSU rDNA sequences, although not all lineages were sampled previously (Hansen et al. 2001).

Group I, supported by $100 \%$ of the bootstrap replicates, include four collections of $P$. vesiculosa and two collections of $P$. ammophila (Figs 1-2). The branch leading to group $\mathrm{I}$ is the longest in the ingroup (54 steps, inclusive dataset, Fig. 3). Furthermore, additional long branches lead to $P$. vesiculosa (25 steps) and to $P$. ammophila (34 steps). Group II includes 33 collections, all with small apothecia, that represent a range of putative species, such as $P$. alcis, $P$. ampliata, $P$. fimeti and $P$. nivalis. Relationships among these taxa are not resolved in the strict consensus tree (Fig. 1) or only with very low support (Fig. 2), but 89-98\% of the bootstrap replicates support monophyly of group II taxa. In general, levels of sequence divergence (ITS rDNA) within group II are low based on the branch lengths (Fig. 3). Nevertheless, sequences of the three collections of $P$. alcis were extremely divergent within the group with a branch length of $33 \mathrm{bp}$ (Fig. 3). Groups IV-VII form a clade B (bootstrap 76-86\%), all of specimens with large apothecia, as a sister group to the specimens with small apothecia, groups II and I or III, (clade A) (Figs 1-3). Within clade B, group VI and VII form a highly supported clade (bootstrap 96-100\%). In the strict consensus tree of the inclusive data set (Fig. 1) group IV, V and VI-VII form a trichotomy. In the strict consensus tree of the exclusive data set (Fig. 2) group IV is a sister group to the groups VI-VII, although bootstrap support is weak (56\%), with group $\mathrm{V}$ as a sister group to these. Group IV includes two collections of $P$. sp. c from Denmark (bootstrap $100 \%$ ). Group V includes two well-supported clades of $P$. arvernensis, group Va contains seven collections of $P$. arvernensis from Denmark and the Netherlands (bootstrap 79-90\%), while $\mathrm{Vb}$ contains two collections from western North America (bootstrap 81-99\%) (Figs $1-3)$. Group VI, which was supported by $94-98 \%$ of the bootstrap replicates, contains two strongly supported lineages of three collections of $P$. echinispora (bootstrap $100 \%$ ) and two collections of $P$. sp. d from western North America (bootstrap 100\%). The next longest branch in the ingroup leads to group VI (38 steps) with the third longest leading to P. echinispora (36 steps) and to $P$. sp. d (36 steps) (inclusive dataset, Fig. 3). Group VII includes 27 collections from the ' $P$. varia complex', including specimens that have been referred to under the names $P$. cerea, $P$. micropus and $P$. repanda (bootstrap 92-97\%). In the analysis of the exclusive dataset two lineages were identified (VIIa, b), but only weakly supported (bootstrap $60 \%$ and $<50 \%$ ). Whereas in analysis of the inclusive dataset four lineages were identified with moderate to high support $(70-100 \%)$, but relationships between these were unresolved.

\section{Group II and VII taxa in separate analyses}

Realignment of the sequences of populations/taxa of each of the groups II and VII allowed unambiguous alignment of more of the molecular characters, with a potential for a more reliable resolution of the fine-scale relationships. The length of the alignment was reduced compared to the alignment including all 86 taxa (Table 3 ), since many fewer gaps were required, thus reducing the possibility of homoplasy. The topology of the strict consensus trees produced with the branch and bound searches (under indel coding) were identical to those produced with heuristic searches (Figs 4, 6). The number of informative characters increased under indel coding (Table 3) and a higher resolution was obtained for group II members, but the resolved nodes yielded 


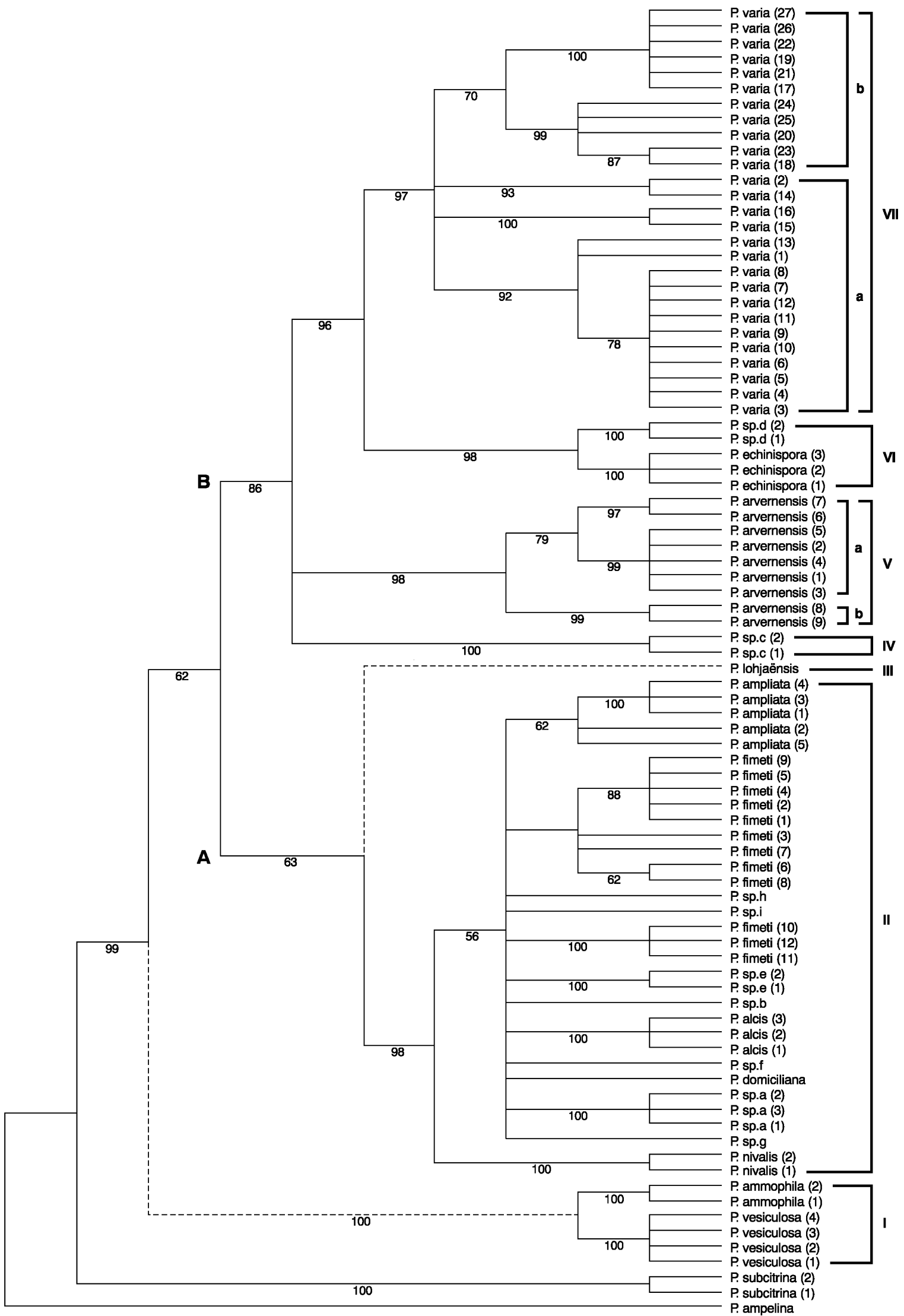

Fig. 1. Strict consensus tree of 15000 most parsimonious trees generated from the inclusive dataset of ITS sequences. Terminal taxa are individual specimens (see Table 1). Numbers below branches are frequency of occurence in 1000 bootstrap replicates (values $<50 \%$ not shown). Bracketed groups I-VII and the two main lineages A and B are discussed in the text. Dashed branches indicate alternate placement of Peziza lohjaënsis and P. vesiculosa/P. ammophila shown in Fig. 2. 




Fig. 2. Strict consensus tree of 15000 most parsimonious trees generated from the exclusive dataset of ITS sequences. Terminal taxa are individual specimens (see Table 1). Numbers below branches are frequency of occurence in 1000 bootstrap replicates. Bracketed groups I-VII and the two main lineages A and B are discussed in the text. Dashed branches indicate alternate placement of Peziza lohjaënsis and P. vesiculosa/P. ammophila shown in Fig. 1. 


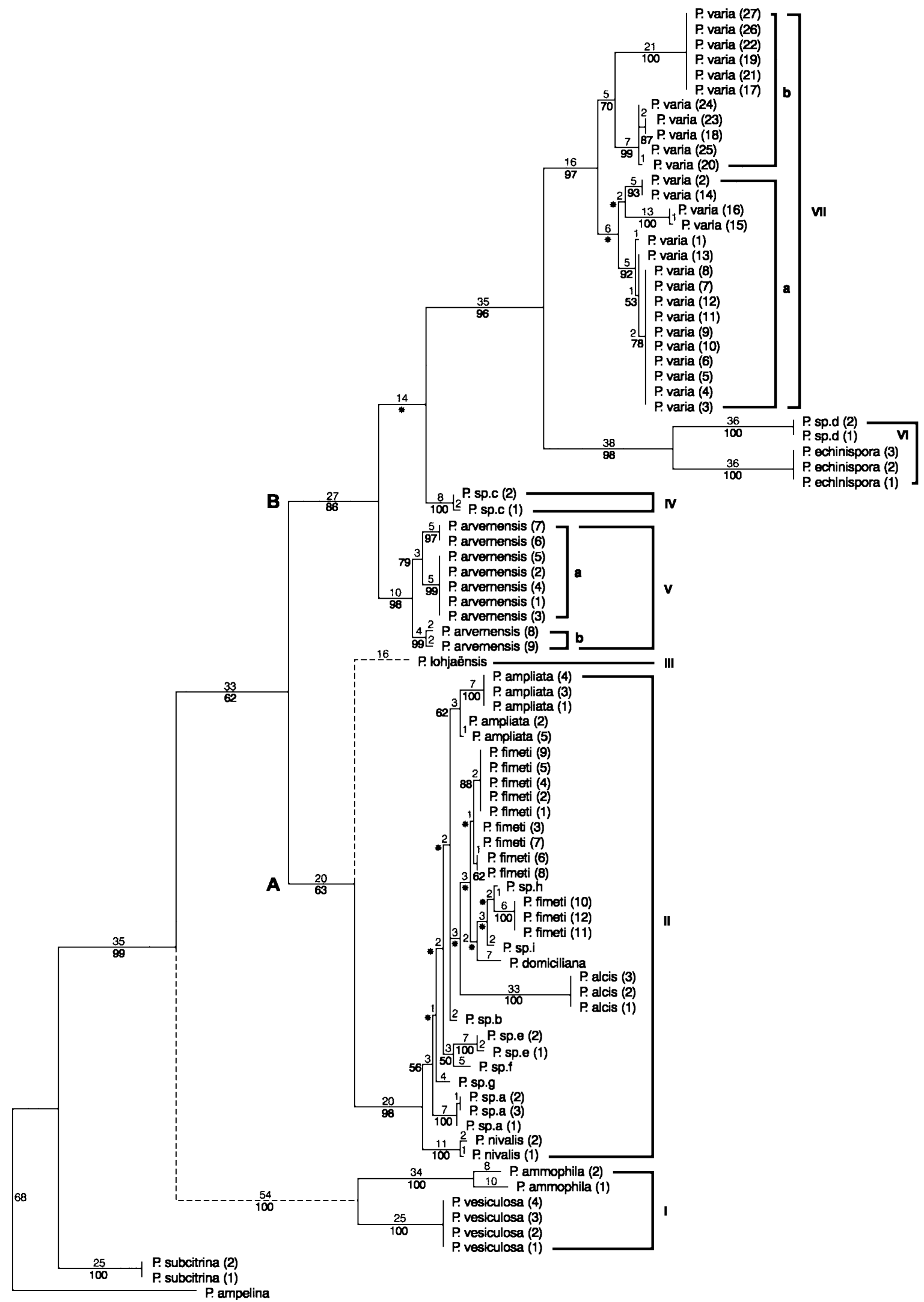

Fig. 3. Phylogram depicting one of 15000 most parsimonious trees generated from the inclusive dataset of ITS sequences. Branch lengths are proportional to the number of steps along the branch. Branches that collapse in the strict consensus tree are indicated with an asterisk. Other symbols are as in Figs 1-2. 
only weak support $(<60 \%)$ (Figs $4-5)$. The strict consensus trees for group VII obtained under the two coding schemes were identical. Therefore, only trees produced under indel coding are presented (Figs 4-7).

Twelve lineages, which represent species or intraspecific entities (Table 4), were supported within group II (Figs 4-5). Lineages represented by more than one sequence were identical or differed only by one or two base pairs and were supported by $100 \%$ of the bootstrap replicates. To a large extent these lineages correlate with distribution, e.g. collections of Peziza sp. a were from Denmark, $P$. sp. e. from Svalbard and Greenland, $P$. nivalis from western North America and $P$. alcis from Finland, Norway and Sweden. P. ampliata was supported by only $67 \%$ of the bootstrap replicates. Within the $P$. ampliata lineage, three collections from Denmark, from large trunks or wood-chips, exhibited identical sequences (bootstrap 100\%). Within the $P$. fimeti lineage, five collections from Russia, Greenland and eastern North America showed almost identical sequences (bootstrap 84\%). However, four collections of $P$. fimeti from Denmark that were almost identical, differed markedly from three other collections from Denmark and the UK, that were likewise almost identical (Fig. 5) (see P. fimeti under 'Taxonomic implications' below). ITS sequences fail to resolve relationships among the twelve lineages (Figs 4-5).

Within group VII two lineages were identified in all MPTs (VIIa, b), congruent with the analysis of the exclusive dataset that included all taxa (Figs 2,6), but they were only weakly supported (bootstrap $55 \%$ and $76 \%$ ). Two divergent and highly supported clades $(100 \%$ bootstrap) are present within group VIIb (Figs $6-7)$. The one is composed of six collections from Denmark and the UK, the other of five collections from Finland, eastern North America and Kamchatka. There were no or few base pair differences among collections within each of these clades (Fig. 7), whereas several base pair differences have accumulated between the clades. Two clades, each of two collections, were highly supported within group VIIa (bootstrap 98 and $100 \%$ ). As a sister group to these, the rest of the group VIIa members form a weakly supported clade (bootstrap $59 \%$ ). In contrast, in analyses of all collections this clade received 92-94\% bootstrap support (Figs 1-3). Group VIIa includes specimens from wide geographical regions (Denmark, Finland, western and eastern North America) but the specimens do not appear in any geographical pattern.

\section{Taxonomic implications}

Based on morphology and ITS rDNA analyses the following taxa are recognized in the core group of Peziza. Selected morphological characters partly supporting the ITS phylogeny are presented in Table 4. The species are listed as they group based on phylogenetic analyses of ITS (I-VII). For each species results are presented and discussed.
Peziza ammophila Durieu \& Lév., Expl. sci. Algérie: pl. 28, fig. 2 and Atlas, Expl. figs: 10 (1868).

Type: No authentic material has been located at PC; Durieu \& Lév., Expl. sci. Algérie: pl. 28, fig. 2 (1847) - lectotypus hic designatus.

Selected descriptions: Maas Geesteranus (1967: 44), Dennis (1981: 17).

Selected illustrations: Seaver (1928: pl. 64), Maas Geesteranus (1967: fig. 52), Dennis (1981: pl. V A).

Notes: Some authors (Moser 1963, Dennis 1981, Dissing 2000) have cited Durieu \& Montagne as the authors of P. ammophila. However, although Montagne was an editor and author of some of the cryptogamic sections, Durieu \& Léveillé were the authors attributed on the plate and in the explanation of Fig. 2 (Durieu \& Léveillé loc. cit.). No description of $P$. ammophila was published when the plate was issued or in supplementary papers before 1868 . Therefore, we conclude that the description of the plate, published in 1868 , constitutes the diagnosis. Plate 28 was first issued in 1847, and Fig. 2 bore the name $P$. ammophila, but this was a nomen nudum until the caption was published in 1868. The plate shows characters in full accordance with the current concept of the taxon. It illustrates one apothecium, a mature ascus and one enlarged spore.

$P$. ammophila is distinguished from the rest of the ingroup by its macromorphology, development and habitat (Table 4). SEM of spores is shown in Fig. 8. ITS sequences of two collections of $P$. ammophila, from Denmark and western North America, form a highly supported clade (bootstrap 100\%), but the sequences differ by several base pairs (pairwise differences: $18 / 601 \mathrm{bp}$ ). No morphological differences were detected. ITS sequences of $P$. ammophila are highly divergent from the rest of the ingroup (Fig. 3).

Peziza vesiculosa Bull., Hist. Champ. France: 270 (1791): Fr., Syst. mycol. 2: 52 (1822).

Type: Bulliard, Hist. Champ. France: pl. 457, fig. $1 \mathrm{~F}$ \& $\mathrm{H}$ (loc. cit.) - lectotypus hic designatus. Bulliard is not known to have preserved herbarium material (Stafleu \& Cowan 1976-88). Fries (loc. cit.) excluded elements of Bulliard's (loc. cit.) original illustration, but a further deviating element (fig. $1 \mathrm{E}$ - too pale and expanded) is excluded here. When introduced, the name $P$. vesiculosa was superfluous, being a later synonym of Bulliard's $P$. cerea, but it is protected by sanctioning (Arts 6.4, 15.1, 52.1). An epitype should be designated when suitable material becomes available, preferably from the type locality.

Selected descriptions: Boudier (1905-10: 139), Dennis (1981: 19), Cacialli, Caroti \& Doveri (1995: 545-549).

Selected illustrations: Boudier (1905-10: pl. 257), Ryman \& Holmåsen (1984: 625), Breitenbach \& Kränzlin (1984: pl. 54), Cacialli et al. (1995: pl. 77).

Notes: The four ITS rDNA sequences of $P$. vesiculosa from different geographical areas (Denmark, the UK and western North America) were completely identical, 
Table 4. Selected morphological characters that characterize the recognized species of Peziza based on the collections used in the molecular phylogenetic study. The taxa are arranged according to the seven (groups I-VII) independent ITS rDNA lineages identified.

\begin{tabular}{|c|c|c|c|c|}
\hline Species & $\begin{array}{l}\text { Apothecia: diam }(\mathrm{cm}) ; \\
\text { shape }\end{array}$ & $\begin{array}{l}\text { Spores: size }(\mu \mathrm{m})^{\mathrm{a}} \text {; } \\
\text { ornamentation LM/SEM; } \\
\text { guttulation }(+/-)\end{array}$ & $\begin{array}{l}\text { Paraphyses: pigments; } \\
\text { shape }\end{array}$ & Substrate \\
\hline \multicolumn{5}{|l|}{ I } \\
\hline P. ammophila & $\begin{array}{l}3-5 ; \\
\text { (pseudo) stipitate, deeply } \\
\text { cup-shaped, spreading } \\
\text { marginal rays }\end{array}$ & $\begin{array}{l}\text { 16-17-18 } \times 8-9-10 ; \\
\text { smooth/smooth; }\end{array}$ & $\begin{array}{l}\text { Hyaline to pale } \\
\text { yellowish; straight, } \\
\text { slightly enlarged at } \\
\text { apex }\end{array}$ & $\begin{array}{l}\text { Sand dunes, often amongst } \\
\text { Ammophila }\end{array}$ \\
\hline P. vesiculosa & $\begin{array}{l}2-10 ; \\
\text { deeply cup-shaped, } \\
\text { margin long incurved, } \\
\text { hymenium wrinkled to } \\
\text { folded towards the centre }\end{array}$ & $\begin{array}{l}20.5-22-24 \times 11-12-12.5 ; \\
\text { smooth/smooth; }-\end{array}$ & $\begin{array}{l}\text { Distinct yellow } \\
\text { guttules, turn golden } \\
\text { in Melzers; enlarged } \\
\text { at apex }\end{array}$ & $\begin{array}{l}\text { Horse manure, straw, hay, } \\
\text { manured soil, mulched } \\
\text { beds }\end{array}$ \\
\hline \multicolumn{5}{|l|}{ II } \\
\hline P. alcis & $\begin{array}{l}\text { up to } 1 \text {; } \\
\text { cup- to disc-shaped, plane } \\
\text { at maturity, finely } \\
\text { crenulate margin }\end{array}$ & $\begin{array}{c}15-16-16.5 \times 7.5-8-9 ; \\
\text { smooth/smooth; }-\end{array}$ & $\begin{array}{l}\text { Hyaline; bent at a } \\
\text { sharp angle at very } \\
\text { apex }\end{array}$ & Dung of elk \\
\hline P. ampliata & $\begin{array}{l}1-2 ; \\
\text { cup- to disc-shaped, } \\
\text { margin } \pm \text { crenulate }\end{array}$ & $\begin{array}{l}\text { 18-19.5-20.5 } \times 9.5-10.5-11.5 ; \\
\text { smooth/smooth; - }\end{array}$ & $\begin{array}{l}\text { Hyaline; straight, } \\
\text { enlarged and slightly } \\
\text { bent at apex }\end{array}$ & $\begin{array}{l}\text { Hardwood trunks, rich soil } \\
\text { mixed with wood-chips, } \\
\text { chalk }\end{array}$ \\
\hline P. domiciliana & $\begin{array}{l}1-2 ; \\
\text { shallowly cup-shaped }\end{array}$ & $\begin{array}{l}14.5-15-15 \times 7-7.5-8 ; \\
\text { fine, regular warts }(\mathrm{LM}) \\
2 \text { small }\end{array}$ & $\begin{array}{l}\text { Hyaline; enlarged at } \\
\text { apex }\end{array}$ & Mortar \\
\hline P. fimeti & $\begin{array}{l}0.5-1.2(-2.5) ; \\
\text { cup-shaped, later often } \\
\text { expanding, margin } \\
\text { crenulate }\end{array}$ & $\begin{array}{l}18-20-22 \times 9.5-11-12.5 \\
\text { smooth/smooth to } \\
\text { roughened; - }\end{array}$ & $\begin{array}{l}\text { Hyaline or with } \\
\text { distinct yellow } \\
\text { guttules; straight or } \\
\text { bent at a sharp } \\
\text { angle, } \pm \text { irregularly } \\
\text { swollen apically }\end{array}$ & $\begin{array}{l}\text { Dung of cow, horse, } \\
\text { reindeer, clayey soil, soil } \\
\text { mixed with wood- } \\
\text { chips/sawdust, burnt } \\
\text { ground }\end{array}$ \\
\hline P. nivalis & $\begin{array}{l}0.6-2 \text {; } \\
\text { disc-shaped, appressed to } \\
\text { soil, margin crenulate, } \\
\text { splitting 3-6 times, often } \\
\text { recurved }\end{array}$ & $\begin{array}{l}\text { 18-19.5-21 } \times 10.5-12-13.5 \\
\text { smooth/ smooth or } \\
\text { slightly granular surface; } \\
-\end{array}$ & $\begin{array}{l}\text { Hyaline; often } \\
\text { moniliform below } \\
\text { top cell (caused by } \\
\text { high level of } \\
\text { moisture) }\end{array}$ & $\begin{array}{l}\text { Soil and decaying grasses, at } \\
\text { edge of melting snow } \\
\text { bank, burnt ground }\end{array}$ \\
\hline$P$. sp. a $(1,2,3)$ & $\begin{array}{l}0.8-2.5 \\
\text { disc- to cupshaped }\end{array}$ & $\begin{array}{l}20.5-22.5-23.5 \times 12-13-14 \\
\text { smooth or finely warty } \\
(\times 1000) / \pm \text { irregularly } \\
\text { dispersed warts; }-\end{array}$ & $\begin{array}{l}\text { Hyaline vacuoles; } \\
\text { straight, slightly } \\
\text { enlarged at apex }\end{array}$ & $\begin{array}{l}\text { Bare clayey, calcareous or } \\
\text { rich soil, disturbed ground }\end{array}$ \\
\hline P. sp. b & $\begin{array}{l}\text { up to } 1.5 \text {; } \\
\text { disc- to shallowly cup- } \\
\text { shaped, margin raised }\end{array}$ & $\begin{array}{l}21-21.5-22 \times 11-11.5-12 ; \\
\text { smooth/smooth or finely } \\
\text { warty; - }\end{array}$ & $\begin{array}{l}\text { Hyaline/yellowish } \\
\text { vacuoles; straight, } \\
\text { club-shaped at apex }\end{array}$ & $\begin{array}{l}\text { Bare soil, under Cirsium, alt. } \\
1800 \mathrm{~m}\end{array}$ \\
\hline$P$. sp. e $(1,2)$ & $\begin{array}{l}0.6-1.8 ; \\
\text { disc-shaped, margin } \\
\text { dentate }\end{array}$ & $\begin{array}{l}19.5-20-21.5 \times 10.5-11.5-12 \\
\text { smooth/smooth or } \\
\text { roughened; - }\end{array}$ & $\begin{array}{l}\text { Reddish-brown } \\
\text { amorphous pigment } \\
\text { on apices; club- } \\
\text { shaped at apex }\end{array}$ & $\begin{array}{l}\text { Silt with running water, } \\
\text { sandy clay }\end{array}$ \\
\hline$P$. sp. f & $\begin{array}{l}0.8-2.1 \\
\text { shallowly cup-shaped, } \\
\text { becoming } \pm \text { plane }\end{array}$ & $\begin{array}{l}21.5-22.5-23 \times 11.5-12-12.5 \\
\text { smooth; }\end{array}$ & $\begin{array}{l}\text { Hyaline to pale } \\
\text { yellowish; straight to } \\
\text { curved at apex, club- } \\
\text { shaped }\end{array}$ & Burnt ground \\
\hline$P . \mathrm{sp} . \mathrm{g}$ & $\begin{array}{l}0.5-1.3 ; \\
\text { disc-shaped with a raised } \\
\text { margin, in age plane }\end{array}$ & $\begin{array}{l}22-24.5 \times 12-14.5 ; \text { smooth } \\
\quad-\end{array}$ & $\begin{array}{l}\text { Pale brown; straight, } \\
\text { club-shaped at apex }\end{array}$ & $\begin{array}{l}\text { Damp, disturbed mineral } \\
\text { soil }\end{array}$ \\
\hline$P . \mathrm{sp} . \mathrm{h}$ & $\begin{array}{l}\text { up to } 1.0 \text {; shallowly cup- } \\
\text { shaped }\end{array}$ & $\begin{array}{l}16-16.5-17 \times 8-9-9.5 \text {; } \\
\text { smooth }\end{array}$ & $\begin{array}{l}\text { Hyaline or pale } \\
\text { yellowish granules; } \\
\pm \text { bent at very apex }\end{array}$ & Dung of beaver \\
\hline$P . \mathrm{sp} . \mathrm{i}$ & $\begin{array}{l}0.4-1.0 \\
\text { shallowly cup-shaped to } \\
\text { disc-shaped, plane }\end{array}$ & $\begin{array}{l}18-18.5-19 \times 9.5-9.5-10 \\
\text { smooth or finely warty, } \\
\text { with thickenings at the } \\
\text { poles }\end{array}$ & $\begin{array}{l}\text { Hyaline or pale } \\
\text { yellowish granules; } \\
\pm \text { bent at apex }\end{array}$ & Dead Phragmites \\
\hline \multicolumn{5}{|l|}{ III } \\
\hline P. lohjaënsis & $\begin{array}{l}1-7 ; \\
\text { cup-shaped, often laterally } \\
\text { compressed }\end{array}$ & $\begin{array}{l}18-19-19.5 \times 9-9.5-9.5 \text {; low, } \\
\text { irregularly dispersed warts, } \\
\text { becoming larger and fused } \\
\text { at the poles }\end{array}$ & $\begin{array}{l}\text { Pale or medium brown } \\
\text { content; club-shaped } \\
\text { at apex }\end{array}$ & $\begin{array}{l}\text { Rich, bare mull and scanty } \\
\text { litter, or on decaying } \\
\text { hardwood, often under } \\
\text { leaves }\end{array}$ \\
\hline
\end{tabular}


Table 4. (cont.)

\begin{tabular}{|c|c|c|c|c|}
\hline Species & $\begin{array}{l}\text { Apothecia: diam }(\mathrm{cm}) \\
\text { shape }\end{array}$ & $\begin{array}{l}\text { Spores: size }(\mu \mathrm{m})^{\mathrm{a}} \text {; } \\
\text { ornamentation LM/SEM; } \\
\text { guttulation }(+/-)\end{array}$ & $\begin{array}{l}\text { Paraphyses: pigments; } \\
\text { shape }\end{array}$ & Substrate \\
\hline \multicolumn{5}{|l|}{ VI } \\
\hline$P$. sp. c $(1,2)$ & $\begin{array}{l}2.8-8.0 \\
\text { deeply cup-shaped, outside } \\
\text { scurfy-scaly, thick-fleshed }\end{array}$ & $\begin{array}{l}18.5-19.5-20.5 \times 9.5-10.5-11 \\
\text { smooth/smooth; - }\end{array}$ & $\begin{array}{l}\text { Hyaline vacuoles; } \\
\text { slightly enlarged at } \\
\text { apex }\end{array}$ & Sawdust and on rich soil \\
\hline \multicolumn{5}{|l|}{ V } \\
\hline P. arvernensis & $\begin{array}{l}2-11 \text {; } \\
\text { deeply cup-shaped, often } \\
\text { irregularly folded from the } \\
\text { sides, margin often } \\
\text { incurved }\end{array}$ & $\begin{array}{l}16-17.5-19(-20) \times 7.5-9-10 ; \\
\text { distinct rounded and } \\
\text { elongated warts, irregularly } \\
\text { spaced, seen on surface } \\
\text { and in outline of spores in } \\
\times 400-1000 / \text { coarse, } \\
\text { rounded to elongated } \\
\text { warts; }-\end{array}$ & $\begin{array}{l}\text { Hyaline; straight, } \\
\text { slightly enlarged at } \\
\text { apex }\end{array}$ & $\begin{array}{l}\text { Soil in connection with } \\
\text { leaves, small branches, or } \\
\text { sawdust }\end{array}$ \\
\hline \multicolumn{5}{|l|}{ VI } \\
\hline P. echinispora & $\begin{array}{l}\text { 1-4.5; } \\
\text { cup-shaped, often irregular } \\
\text { compressed, expanding in } \\
\text { age }\end{array}$ & $\begin{array}{l}15.5-16.5-17 \times 7.5-8-9 \text {; high } \\
(0.5-1 \mu \mathrm{m}) \text {, isolated, regular } \\
\text { warts or spines, often denser } \\
\text { at the poles; }-\end{array}$ & $\begin{array}{l}\text { Hyaline or pale } \\
\text { yellowish vacuoles; } \\
\text { straight, enlarged at } \\
\text { apex }\end{array}$ & Burnt ground \\
\hline$P$. sp. d $(1,2)$ & $\begin{array}{l}\text { 1.1-5.5; } \\
\text { deeply cup-shaped }\end{array}$ & $\begin{array}{l}19-21-22.5 \times 10.5-11-12.5 \\
\text { smooth; }-\end{array}$ & $\begin{array}{l}\text { Hyaline; straight, } \\
\text { enlarged at apex }\end{array}$ & $\begin{array}{l}\text { Soil mixed with wood chips, } \\
\text { bare disturbed soil }\end{array}$ \\
\hline \multicolumn{5}{|l|}{ VII } \\
\hline P. varia & $\begin{array}{l}2-15 ; \\
\text { cup-shaped to expanded, } \\
\pm \text { folded, sometimes finally } \\
\text { convex and with a } \\
\text { depressed centre, funnel- } \\
\text { shaped, often with a } \\
\text { distinct, lighter coloured, } \\
\text { crenulate margin }\end{array}$ & $\begin{array}{l}14.5-16-17.5 \times 8-9.5-10.5 ; \\
\text { smooth or very fine, dense } \\
\text { warts to fine warts } \\
(\times 1000), \text { seen on surface, } \\
\text { not in outline of spores } \\
\text { or/very low, fine warts to } \\
\text { fine, regular low warts; }-\end{array}$ & $\begin{array}{l}\text { Hyaline or pale } \\
\text { yellowish; slightly } \\
\text { enlarged at apex }\end{array}$ & $\begin{array}{l}\text { Large decorticated hard- } \\
\text { wood trunks: Fagus, } \\
\text { Quercus, Betula, Populus, } \\
\text { Salix, Ulmus, or plaster, } \\
\text { brick walls, typically in } \\
\text { wet basements, gravel, } \\
\text { sawdust and rich soil }\end{array}$ \\
\hline
\end{tabular}

a smallest and largest spore size (excluding aberrant ones) in the collections studied, and the average of all.

but highly divergent from those of the other taxa in the ingroup (Fig. 3). The distinction is evident as well from morphological features displayed by $P$. vesiculosa, such as size and shape of the apothecia, distinct yellow guttules in the paraphyses (Boudier, loc. cit.: pl. 257) which turn golden in Melzer's reagent, large, smooth spores (Fig. 9) and the habitat, being restricted to \pm manured straw or hay, richly manured soil and mulched beds, but apparently not or rarely directly on dung. $P$. fimeti has been confused with $P$. vesiculosa, because it occurs on dung and has smooth spores within the same size range, but $P$. fimeti differs in the small, discoid apothecia and other characters (Table 4). Separate analyses of ITS and LSU rDNA data suggest that $P$. vesiculosa and species with small apothecia on dung are highly divergent and occur in separate lineages within the core group of Peziza.

Peziza alcis Harmaja, Karstenia 26: 44 (1986); as 'alcidis'.

Type: Finland: Uusimaa: Inkoo, Rådkila, alt. ca 15 $\mathrm{m}$, grid $27^{\circ}$ E 6665:339, \pm mesic acid coniferous heath forest, on dung of Alces, 9 Nov. 1977, H. Harmaja (H - holotype!).

Selected description: Harmaja (1986).

Selected illustration: None.
Notes: The three ITS rDNA sequences of $P$. alcis from Finland (holotype), Norway and Sweden were identical, but extremely divergent from the rest of the taxa with small apothecia, which otherwise were very uniform (Figs 3, 5). Nevertheless, the ITS data does support $P$. alcis within group II (Figs 1-2). Likewise, based on morphological criteria, $P$. alcis appears to be closely related to the rest of the group II members. Within this group it is distinguished by its small spores (Fig. 10), paraphyses characteristically bent at the apex (slightly enlarged and hooked at the tips), and occurrence on elk dung.

One collection, $P . \mathrm{sp} . \mathrm{h}$, fruiting on dung of beaver, is morphologically indistinguishable from the collections of $P$. alcis, but differences in its ITS sequence led to its grouping with a collection on reed litter, labeled as $P$. sp. i. These collections require further study and recollecting.

Peziza ampliata Pers., Icon. descr. fung. 2: 31, tab. 8, fig. 6 (1800): Fr., Syst. mycol. 2: 76 (1822).

Type: No authentic material has been located in the Persoon herbarium in L; Persoon (loc. cit.): tab. 8, fig. 6 - lectotypus hic designatus.

Selected descriptions: Svrček (1970: 59), Dennis (1981: 18). 
Selected illustrations: Boudier (1905-10: pl. 264), Svrček (1970: figs 1 A-B, 2).

Notes: $P$. ampliata is recognized by small apothecia, up to $2(-3) \mathrm{cm}$ diam, a rather thick flesh in comparison with the size of the apothecia ( $c a 1-3 \mathrm{~mm}$ thick), occurrence on large trunks or smaller pieces of hardwood, and by large, smooth spores (Fig. 11) compared to $P$. varia (Figs 20-25, Table 4). The apothecia are sessile on a broad base or broadly substipitate and are at first shallowly cup-shaped then expanded and flattened. The hymenium is yellowish brown to brown, and may have an olivaceous tint (observed for $P$. ampliata specimens 1 and 4). $P$. ampliata has been described with a non-stratified medullary exciple i.e. without a hyphal middle layer between two layers of globose cells (e.g. Svrček 1970, Dennis 1981). Nevertheless, we found apothecia both with and without stratified exciples. The type plate of $P$. ampliata depicts a single, medium brown, $24 \mathrm{~mm}$ wide, sessile apothecium on a decayed piece of wood.

Three of the ITS sequences, from typical $P$. ampliata specimens occurring on wood, were identical (Fig. 5). Two additional collection are provisionally referred to $P$. ampliata, based on ITS, although bootstrap support was low (67\%). One of these, P. ampliata (5), differs by the substrate being lime. Only specimens from Denmark were included in the molecular study.

Peziza domiciliana Cooke, Gard. Chron. 41 : 793 (1877).

Type: United Kingdom: Scotland: Edinburgh, on damp walls, Inverleith House, Balfour (K - holotype, $\mathrm{PC}$ - isotype).

Peziza adae Sadler, in Cooke, Trans. bot. Soc. Edinb. 13: 45 (1877): nom. superfl. (Art. 52.1).

Selected description: Maas Geesteranus (1967: 49).

Selected illustrations: Cooke (1879: pl. 97, fig. 349), Maas Geesteranus (1967: fig. 61, spores only).

Excluded illustration: Breitenbach \& Kränzlin (1984: pl. 40) (= P. varia) .

Notes: Type material of $P$. domiciliana was studied by Le Gal (1941; as Galactinia adae) and Rifai (1968). They both described and illustrated the spores as minutely warted (Le Gal 1941: fig. 27, Rifai 1968: fig. 252), a character not mentioned in the original description. Like $P$. varia, $P$. domiciliana occurs on damp walls, plaster and mortar. These species have been confused, but $P$. domiciliana differs from P. varia by its small (Cooke: $13 \times 6-7 \mu \mathrm{m}$; Le Gal: 12 $14(15) \times 6-9 \mu \mathrm{m}$ ), finely warted spores (easily seen in $\mathrm{LM} \times 1000$ ) with two small guttules. It is the only species within the core group of Peziza that has guttulate spores. Only a single collection with small apothecia (in C) referable to $P$. domiciliana has been seen. ITS rDNA sequences suggest $P$. domiciliana is closely related to the species with small apothecia (group II), nonetheless its obvious ability to produce apothecia up to $5 \mathrm{~cm}$ (Cooke 1879, Maas Geesteranus 1967).
Peziza fimeti (Fuckel) E. C. Hansen, Vidensk. Meddel. Dansk Naturhist. Foren. Kjobenhavn: 267 (1876).

Humaria fimeti Fuckel, Jahrb. Nassauischen Ver. Naturk. 25-26: 338 (1871).

Type: [Germany: Nassau] auf Kuhmist, in einem Tannenwalde, unterhalb Mappen. Vere. Herb. BarbeyBoissier ( $\mathrm{G}$ - holotype!; FH - isotype!).

Peziza bovina W. Phillips, in Stevenson, Mycol. Scot.: 308 (1879).

Type: [Scotland: Grampian] Peziza (Humaria) bovina ns. Grantown, on cow dung, Aug. 1878, J. Keith 80 (K(M): 59523 - holotype!).

Peziza granularis Donadini, Bull. Soc. Linn. Prov. 30: 73 (1977); nom. illegit. This was a replacement name for Aleuria granulosa (Schum.) Gillet sensu Boudier. Donadini should have described this taxon as a new species, and supplied a Latin diagnosis (Spooner \& Yao 1995).

Misapplication: Peziza granulosa Schum. sensu Cooke (1879) and Boudier (1905-10). Boudier's material of Aleuria granulosa, 'Montmorency, Junio 1879, Ipse Pegi Boudier, vit. Icones' (PC, herb. Boud.), was examined. The spores measured 19.5-20.5-21.5 × 1111.5-12 $\mu \mathrm{m}$, fall within the range of $P$. fimeti.

Excluded: Peziza granulosa Schum., Enum. pl. 2: 415 (1803).

Type: Schumacher, Flora Hafniensis Fungi Delineati (unpubl.): fig. 131 (macroscopic colour drawing)lectotypus hic designatus. Schumacher's fig. 131 illustrates a species with much larger apothecia $(\times 2-3)$ than the species which has been referred to as P. granulosa following Cooke (1879) and Boudier (1905-10). Schumacher did not illustrate or describe any microscopic characters. Fries (1822), who studied Schumacher's aquarelles, correctly listed $P$. granulosa under $P$. repanda.

Peziza fimetosa Fr., Syst. mycol. 2: 73 [index: 621] (1822, 1823); syn. P. fimetaria Schum., Enum. pl. 2: 426 (1803) non Pers.

Type: Schumacher, Flora Hafniensis Fungi Delineati 3 (unpubl.): pl. 123, fig. 3 (2 separate drawings)lectotypus hic designatus. Schumacher's plate most likely shows a species of Pseudombrophila; the apothecia are too small for $P$. fimeti (ca $50 \%$ smaller). Bresadola (1933) erroneously used the name Humaria fimetaria for $P$. fimeti.

Selected descriptions: Svrček \& Kubicka (1961: 74), Gamundí (1975: 26), Cacialli et al. (1995: 539-541).

Selected illustrations: Boudier (1905-10: pl. 272; as A. granulosa), Bresadola (1933: tab. 1231, 2), Gamundí (1975: pl. 6), Breitenbach \& Kränzlin (1984: pl. 43; as 'Aleuria' hortensis), Cacialli et al. (1995: pl. 76).

Notes: We consider the material of P. fimeti in G (several apothecia still attached to dung in reasonable good condition) to be the holotype, since it has an original Fuckel drawing and label (with substrate and locality) attached. Material in FH has the same locality noted on the envelope. Both the original description 
and the attached drawing of $P$. fimeti give the spores as $16 \times 8 \mu \mathrm{m}$. In contrast, spores from the holotype measure $20-21.5-22.5 \times 10-11-12 \mu \mathrm{m}$, which is in accordance with the material studied by us, on dung of cow, horse, sheep and reindeer from Denmark, Finland, Greenland, Norway, Russia (Sakha) and USA (New Mexico) (Figs 12-13). Although several keys and descriptions list $P$. fimeti $i$ ith the spore size as given by Fuckel (Seaver 1928, Bresadola 1933, Moser 1963, Dennis 1981, Romagnesi 1978, Dissing 2000), others (Svrček \& Kubicka 1961, Gamundí 1975, Donadini 1977, 1979) do report larger spores (in the range of 18.5-21.5 $\times 9.5-12 \mu \mathrm{m})$. According to Spooner \& Lundqvist (pers. comm.) the only known species of Peziza with small apothecia and smooth spores on dung of cow and horse in the UK and Sweden has large spores ( $c a 18-22 \times 10-12 \mu \mathrm{m}$ ). Based on our observations it seems most likely that only one smoothspored species, $P$. fimeti, occurs on cow and horse dung and that the measurement given by Fuckel was a simple mistake, which has been perpetuated in the literature. We have studied the holotype of P. bovina and the spores measure 19.5-20.5-21 × 10.5-11-12 $\mu \mathrm{m}$ (in agreement with Gamundí 1975).

Based on ITS sequences and morphology we found no justification for separating $P$. granulosa sensu Boudier and Cooke from P. fimeti. These two species have been distinguished mainly on substrate, e.g. rich soil among herbs, soil mixed with sawdust and woodchips, or burnt ground vs cow, horse and other herbivores dung. In addition, according to Boudier (1905-10), the paraphyses in $P$. granulosa contain distinct yellow guttules and are often irregularly swollen apically and tend to be bent at a sharp angle (observed in e.g. TL-4935, KH-98-26 and KH 00.012 but not in KS-94-12). This character is difficult to observe on dried material and we have not been able to confirm it in collections from dung, but Svrček \& Kubicka (1961) described it from material on cow dung. To a certain degree the guttulation/pigments of the paraphyses may be dependent on the light conditions during development of the apothecia. ITS sequences of two Danish collections, one from dung and the other from soil mixed with woodchips/sawdust, were identical (Figs 4-5). Likewise, ITS sequences of Russian and western North American collections from dung were identical to one Russian collection from clayey soil. A constraint analysis, using the group II dataset, forcing monophyly of the clades of P. fimeti (10-12) and P. fimeti (1-9) did not yield trees that were significantly worse (KishinoHasegawa test, $P<0.05$ ) than the unconstrained trees (Figs 4-5).

In our concept $P$. fimeti is characterized by small apothecia (most often not exceeding $2 \mathrm{~cm}$ ), with a crenulate margin, and a nearly smooth to strongly furfuraceous outer surface (pustules of globose cells) and spores $18-20-22 \times 9.5-11-12.5 \mu \mathrm{m}$.
Peziza nivalis (Heim \& Remy) M. M. Moser, in Avizohar-Hershenzon \& Nemlich, Israel J. Bot. 23 : 162 (1974).

Galactinia nivalis Heim \& Remy, Bull. Soc. mycol. France 48: 63 (1932).

Type: No authentic material has been located in PC. Selected descriptions: Breitenbach \& Kränzlin (1984: 74), Pfister (1992: 171-172).

Selected illustrations: Breitenbach \& Kränzlin (1984: pl. 48).

Notes: Although there has been considerable confusion over the application of the name $P$. nivalis and other names for specimens found on soil at the margin of melting snow, Pfister (1992) placed three names in the synonymy of $P$. nivalis: $P$. ninguis, $P$. fortoulii, and $P$. phaeotheca. ITS sequences of two collections of $P$. nivalis from western North America were almost identical and well-separated within the otherwise homogenous group II, with a branch length of 11 to 18 bp (Figs 3, 5). P. nivalis is mainly separated from other species of group II by its habitat (Table 4). It should be noted that collections of $P$. nivalis made by K. H. in the Sierra Nevada, California, always occurred next to decaying grasses, often on burnt ground. SEM of spores is shown in Fig. 14.

\section{Putative species or intraspecific entities within group II:} Peziza sp. a, b, e, f, g, h and i

A number of specimens not yet identified, referred to as Peziza sp. a, b, e, f, g, h and i, form separate lineages within group II, or are kept separate based on substrate or morphology (Fig. 4). These may represent distinct species, but the lack of well-supported resolution between the lineages within group II (Figs 4-5), provides no basis for taxonomic differentiation (see 'Group II and VII taxa in separate analyses' above), and indicates that the morphological characters used and differences in habitat are plastic and not informative for species distinctions in this complex. Peziza sp. a, f, g have slightly larger spores (Fig. 15) than the rest of group II, $P$. sp. e has an amorphous pigment, that covers the apices of the paraphyses, and others occur on distinctive substrates (Table 4).

\section{Peziza lohjaënsis Harmaja, Karstenia 26: 46 (1986).}

Type: Finland: Varsinais-Suomi: Lohja rural commune, Jalassaari, Heimo, alt. 45 m, grid $27^{\circ}$ E 6682:329, slightly moist, predominantly deciduous (e.g. Populus tremula), rich woods on somewhat calcareous ground, on bare mull, 30 May1982, H. Harmaja (H - holotype!).

Selected description: Harmaja (1986: 46-47).

Selected illustration: Harmaja (1986: figs 4-5).

Notes: P. lohjaënsis has a unique ITS sequence, and its relationship within the ingroup is uncertain. Unfortunately only one collection was available for molecular study, so intraspecific diversity could not be explored. P. lohjaënsis is so far known only from 

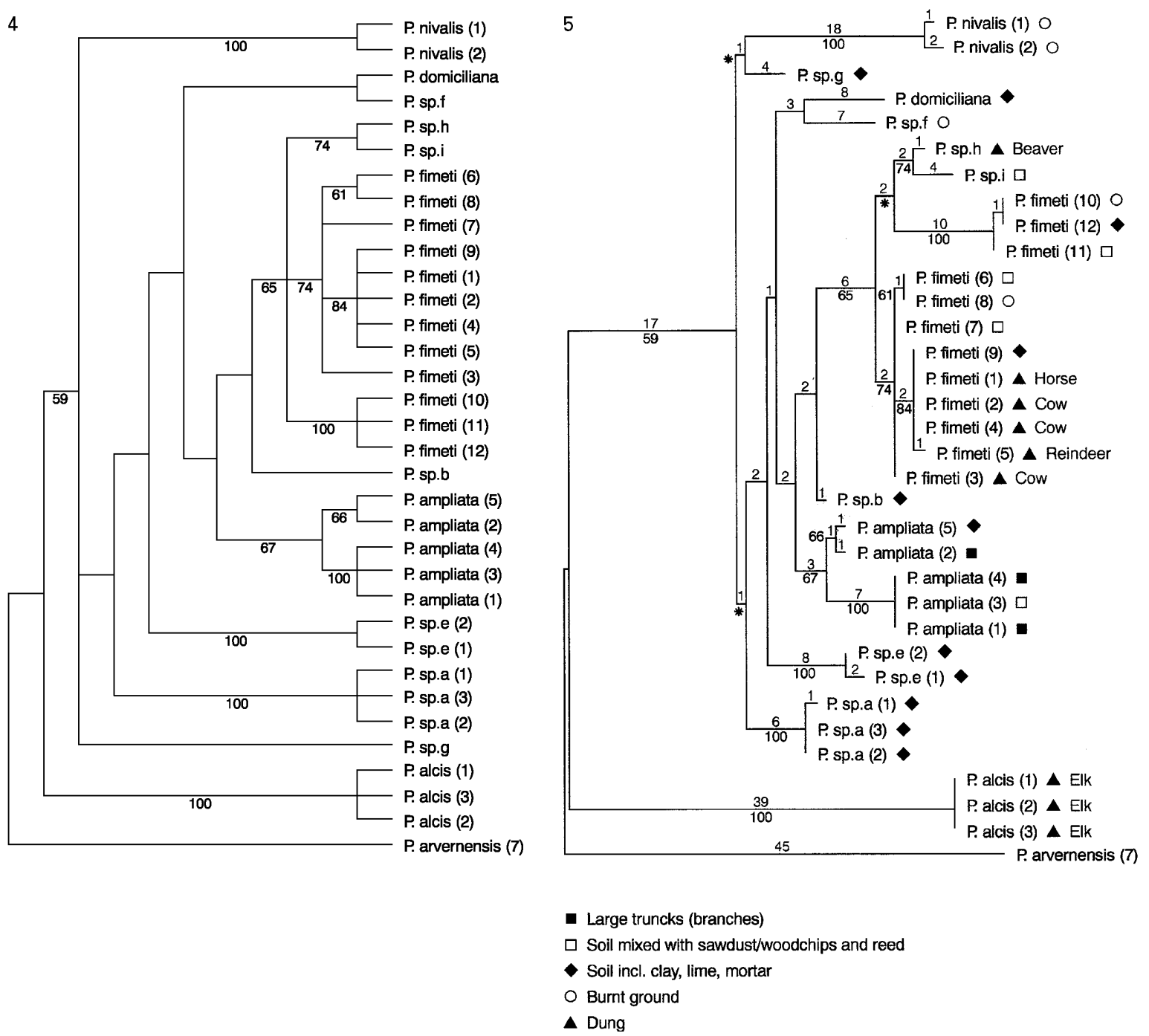

Figs 4-5. Phylogenetic trees generated under indel coding for realigned data of group II. Terminal taxa are individual specimens. Numbers by branches in black are frequency of occurence in 1000 bootstrap replicates (values $<50 \%$ not shown). Fig. 4. Strict consensus tree of 108 most parsimonious trees. Fig. 5. Phylogram depicting one of 108 most parsimonious trees. Branch lengths are proportional to the number of steps along the branch. Symbols by specimen names indicate the substrate according to the legend.

southern Finland (Harmaja 1986). It is recognized by the spore ornamentation in combination with the large apothecia, asci with brownish walls and paraphyses with a pale or medium brown content (Table 4). Spore measurements from the holotype (Table 4) are in the range given by Harmaja (1986).

\section{Peziza sp. c}

Completely smooth spores in LM and SEM characterize this species. In addition, Peziza sp. c is distinguished from $P$. varia by the larger spores (Table 4 ). The exciple structure is of four layers (not including the subhymenium) as is typical for $P$. varia and $P$. arvernensis. Only the two collections of $P$. sp. c sampled for molecular studies have been seen. These showed rather thick-fleshed apothecia (1.5-3 mm thick), with a scurfyscaly outside, and with the hymenium constricted in the centre forming ribs. Colours of the hymenium are yellow to grey brown. The two ITS sequences of $P$. sp. c from Denmark were almost identical (group IV), and well-separated from the rest of the ingroup (Figs 1-3). Peziza sp. c should be described when more material becomes available, or a name may be traced when further revisions are undertaken.

Peziza arvernensis Roze \& Boud., Bull. Soc. bot. France 26: 76. pl. 3, fig. 4 (1879).

Type: No authentic material has been located at PC; Roze \& Boud. (loc. cit.): pl. 3, fig. 4 (a, b, c) - lectotypus hic designatus.

? Peziza sylvestris (Boud.) Sacc. \& Traverso, Syll. fung. 22: 612 (1913).

Aleuria sylvestris Boud., Icon. mycol. livr. 10: $\mathrm{n}^{\circ} .136$, pl. 261 (1906) [preliminary text of Icon. mycol. with 'circulaires'].

Type: No material from the type locality, Fontainebleau, has been located at PC. However, material from the Boudier herbarium (PC) from 'Montmorency 
(Seine-et-Oise) - France - 10 juin 1891', 'Lyon misit Dr. Riel (Julio)' and 'Pierrefonds Oct. 1889, ad terram humosam in fagetis', has been examined. These specimens previously were studied by Le Gal (1941), who found, as we have, that the spores are finely warted. On the contrary, Boudier described and illustrated the spores as smooth, but with very small vacuoles. The spores measure 16-16.5-17.5 ×9-9.5 $\mu \mathrm{m}$ (Boudier 17-18 $\times 9-10 \mu \mathrm{m}$ ). The status of this name will remain unclear until the type material is traced or a neotype is selected. Most authors have followed Le Gal (1941) in using the name P. sylvestris for a warty-spored species (Svrček 1970, Donadini 1977, Hohmeyer 1986, Dissing 2000) and often placed it in synonymy with Boudier's $P$. arvernensis. Seaver (1928) used P. sylvestris for a smooth-spored species on rubbish piles and soil in woods, but noted that it could possibly be $P$. cerea .

Selected descriptions: Svrček (1970: 75-76).

Selected illustrations: Boudier (1905-10: pl. 261), Breitenbach \& Kränzlin (1984: pl. 36).

Notes: The type plate of $P$. arvernensis depicts a single, deeply cupshaped, apothecium, in black and white, $56 \mathrm{~mm}$ wide, punctate-warty spores and asci.

The nine included collections of $P$. arvernensis form a monophyletic group in all MPT's (bootstrap 58\% and $98 \%$, Figs $1-3$ ). Two geographical lineages were identified, one consisting of collections from Denmark and the Netherlands (Va), and the other with material from western North America ( $\mathrm{Vb})$. Four ITS sequences from Denmark and one from the Netherlands were identical, but differed by several nucleotides from two additional sequences from Denmark (Fig. 3). The spore ornamentation in the two latter collections was much finer, but otherwise these specimens did not seem to differ. The two specimens from western North America showed almost identical ITS sequences.

$P$. arvernensis can easily be confused with $P$. varia, but is distinguished from other members of lineage B by the spore ornamentation, of both rounded and elongated warts, which are irregularly and widely spaced and can be seen both on the surface and in the outline of the spores by LM $(\times 400 / 1000)$ and by SEM. The warts are $c a 0.3-0.5 \mu \mathrm{m}$ high (Figs 17-18). In addition, $P$. arvernensis occurs on soil with leaves, small branches or sawdust, typically in beech forest.

Peziza echinispora P. Karst., Fungi fenn. exs. no. 541 (1866).

Type: Fungi fenniae Exsiccati no. 541 (1866) (H!) - lectotypus hic designatus, FH!, K fide Rifai (1968) - isolectotypes.

Aleuria umbrina Boud., Icon. mycol. pl. 279 (1905-10).

Peziza anthracophila Dennis, Bri. Cup Fungi: 13

(1960); nom. nov. for A. umbrina Boud. non Pers. 1822.

Type: Not studied.

Selected descriptions: Karsten (1871: 54-55), Rifai (1968: 228), Dennis (1981: 20).

Selected illustrations: Boudier (1905-10: pl. 279; as
A. umbrina), Le Gal (1941: fig. 6; as A. umbrina, spores only), Maas Geesteranus (1967: fig. 62), Dennis (1981: pl. V F), Breitenbach \& Kränzlin (1984: pl. 41).

Notes: Spores of the lectotype measure 15.5$16.5-17 \times 7.5-8-9 \mu \mathrm{m}$, which is in the range given by Karsten $(1869,1871)$. The taxonomy and nomenclature of P. echinispora poses no problems. Both molecular and morphological characters support $P$. echinispora as a well-separated species/lineage. The spore ornamentation composed of isolated, regular spines, up to $1 \mu \mathrm{m}$ high (Fig. 19), is unique within the ingroup. Nevertheless, characters such as eguttulate spores, an Oedocephalum anamorph and the amyloid ascus ring zone, justify its placement in the core group of Peziza. To our knowledge, P. echinispora is only found fruiting on burnt ground. The three ITS sequences of $P$. echinispora from Denmark, Finland and eastern North America were identical (Fig. 3).

\section{Peziza sp. d}

Peziza sp. d, from Denmark, appears morphologically identical to $P$. sp. c, from Oregon, except for the slightly larger spores. However, phylogenetic analyses do suggest that these are not conspecific. ITS sequences from the two collections of $P$. sp. d were identical and form a monophyletic group with $P$. echinispora (group VI) (Figs 1-3).

Peziza varia (Hedw.: Fr.) Fr., Syst. mycol. 2: 61 (1822).

Octospora varia Hedw., Descr. micr-anal. musc. frond. 2: 22, tab. 6 D (1789): Fr., Syst. mycol. 2: 61 (1822).

Type: No authentic material has been located in $\mathrm{G}$; Hedwig (loc. cit.): tab. 6 D (figs 1-5)-lectotypus hic designatus. Epitype: Denmark: Aarhus, Fuglesangsallé 88 , on concrete wall damaged by water in a basement, 4 Aug. 1997, J. H. Petersen, KH-97-54 (C). Additional collections from the locality are deposited in $\mathrm{C}$ and $\mathrm{FH}$.

Peziza micropus Pers., Icon. descr. fung. 2: 30, tab. 8. fig. 3 (1800): Fr., Syst. mycol. 2: 54 (1822).

Type: No authentic material has been located in the Persoon herbarium in L; Persoon (loc. cit.): tab. 6, fig. 3 -lectotypus hic designatus.

Peziza cerea Fr., Syst. mycol. 2: 52 (1822): Fr., loc. cit.; non P. cerea Bull., Herb. Fr.: tab. 44 (1780).

Type: Sowerby, Engl. Fungi 1: tab. 3 (1797)lectotypus hic designatus. Since Fries (loc. cit.) excluded the Bulliard type of $P$. cerea by not referring to tab. 44 , the name should be treated as authored by Fries alone (Art. 48). Among the descriptions cited by Fries was that of Sowerby (loc. cit.) which represents a fungus that we consider conspecific with $P$. varia. A case could also be made for regarding $P$. cerea as a nomen ambiguum but, since modern use of the epithet is consistent with our sense of $P$. varia, the proposed synonym is the clearest solution. Bulliard's fungus most likely is $P$. vesiculosa. 
Excluded: Peziza repanda Pers., Icon. pict. sp. fung. 4 : 49 (1808): Fr. Syst. mycol. 2: 51-52 (1822).

Type: No authentic material has been located in the Persoon herbarium in L. A case could be made for selecting the original Persoon plate (loc. cit.: pl. 20, fig. $2[b i s])$ but this would not clarify the status of this name. Persoon described the habitat of $P$. repanda as in sylvaticis ad terram'. Fries (loc. cit.) used the name for a species on old trunks, primarily of Fagus, but also included blackened soil [burnt ground] as the substrate. Some authors have followed Persoon in respect to substrate (Dennis 1981, Dissing 2000, Spooner 2001), others Fries (e.g. Seaver 1928), and still others have used the name for a species occurring on soil and only exceptionally on wood (Rifai 1968, Hohmeyer 1986). In all cases the name has been used for a species with smooth spores in the size range given for $P$. varia. We have not seen material of $P$. varia on bare soil (without mortar, lime, sawdust, etc.). Since the name lacks a type specimen and has been used inconsistently it is best treated as of uncertain application.

Selected descriptions: Rifai (1968: 233-234, 237-240; as $P$. varia, $P$. cerea), Svrček (1970: 64-74; as P. cerea, P. micropus, P. varia), Dennis (1981: 18, 21; as $P$. miropus, P. varia, P. cerea).

Selected illustrations: Boudier (1905-10: pl. 259; as Aleuria cerea, pl. 267; as A. varia, pl. 268; as $A$. micropus), Svrček (1970: figs 3 AB, 5 A-G, 8 A-C), Breitenbach \& Kränzlin (1984: pl. 40; as P. domiciliana), Ryman \& Holmåsen (1984: 624-625; as $P$. cerea and P. repanda).

Notes: Hedwig's $P$. varia plate depicts two, brown, stipitate apothecia up to $48 \mathrm{~mm}$ wide, and some immature specimens on the substrate, and remarkably, a section showing the hymenium and exciple structure, including the stratified medullary exciple. Persoon's plate of $P$. micropus illustrates a single, brownish, stipitate apothecium, $18 \mathrm{~mm}$ wide, with a strongly furfuraceous, paler outside, on a piece of wood. Sowerby's $P$. cerea plate contains a range of pale yellowish brown, stipitate, more or less funnel-shaped apothecia in various stages of maturity, up to $61 \mathrm{~mm}$ wide, some on the substrate, others cut off.

Phylogenetic analyses of ITS sequences supports the 27 collections of the ' $P$. varia complex' as one monophyletic group (group VII, bootstrap 92-97\%) (Figs 1-3). Two lineages were identified (VIIa, b) (Figs 2, 6-7), which could possible represent two species. Group VIIa members are morphologically united by slightly finer spore ornamentation than group VIIb members. Spores within group VIIa appear smooth or nearly smooth in LM $(\times 1000)$ and have very low, dense warts in SEM, ca $0.1 \mu \mathrm{m}$ high (Figs 20-22), whereas spores within group VIIb appear finely warted on the spore surface in LM $(\times 1000)$, and have fine, dense warts in SEM, up to $c a 0.4-0.5 \mu \mathrm{m}$ high (Figs 23-25). In addition, group VIIb specimens were found exclusively on large hardwood trunks, with the group of collections from Denmark and the UK typically on
Fagus (P. varia (26) was on Quercus) (100\% bootstrap), and with the group from Finland, eastern North America and Kamchatka on Acer, Betula, Populus and Ulmus (100\% bootstrap) (Figs 6-7, Table 4). Several specimens within group VIIa, however, were likewise found on large hardwood trunks (Table 4), of both Fagus, Populus, Salix and Ulmus, besides being found on sawdust and on rich soil with sawdust, on plaster in basements, brick walls, on gravel etc. (Fig. 7). The name $P$. cerea primarily has been used for specimens occurring on plaster covering timber or straw, brick walls or on coarse sand in wet basements and garages, on limestone or on soil mixed with mortar (Maas Geesteranus 1967, Svrček 1970, Dissing 2000, Spooner 2001), but also on woody debris, rotting sandbags etc. (Rifai 1968, Dennis 1981) whereas the names $P$. micropus and $P$. repanda sensu Fries have been used for specimens on decayed hardwood trunks. ITS sequences from specimens on the floor and walls in basements, were identical or nearly identical to ITS sequences from some of the specimens on large hardwood trunks (Figs 6-7).

Apart from the subtle difference in the spore markings, we found no morphological features that support the division of group VII in two (VIIa, b) or five species, equivalent to the well-supported clades identified in analyses of the inclusive dataset (Figs 1, 3). Since analyses of ITS only supported the two lineages VIIa and VIIb with $55-60 \%$ and $<50-76 \%$ of the bootstrap replicates respectively, we found no justification for recognizing more than one species, $P$. varia, within group VII. It should be noted that the ' $P$. varia complex' in general is described as smooth spored, although it previously has been shown by SEM (Berthet 1970, Donadini 1977, 1979) that the spores are finely ornamented. The warts can often be observed in LM, but sometimes the spores appear smooth.

$P$. varia has been distinguished from $P$. cerea and $P$. micropus by the presence of moniliform paraphyses (e.g. Rifai 1968, Dennis 1981, Ginns 1980, Dissing 2000, Spooner 2001). However, as already observed by Donadini (1980b) and Kullman (1995), we found the development of moniliform paraphyses in specimens within this group (and in group I and II) to be a result of high levels of moisture in the micro-environment, which make the cells in the paraphyses swell. Svrček (1970) also noted that this character was without any taxonomic value.

According to Svrček (1970), P. cerea most often develops apothecia with a medullary exciple of globose cells, lacking a middle layer of interwoven hyphae, running parallel with the outer surface (a stratified exciple) characteristic of $P$. micropus and $P$. varia. Dennis (1981) used the name $P$. micropus for a species with a non-stratified exciple. We observed a stratified exciple in all specimens, but of very variable thickness ((30-)60-280 $\mu \mathrm{m}$ thick) and often difficult to discern in dried material. We found no correlation between the ITS lineages and the thickness of the hyphal layers or 

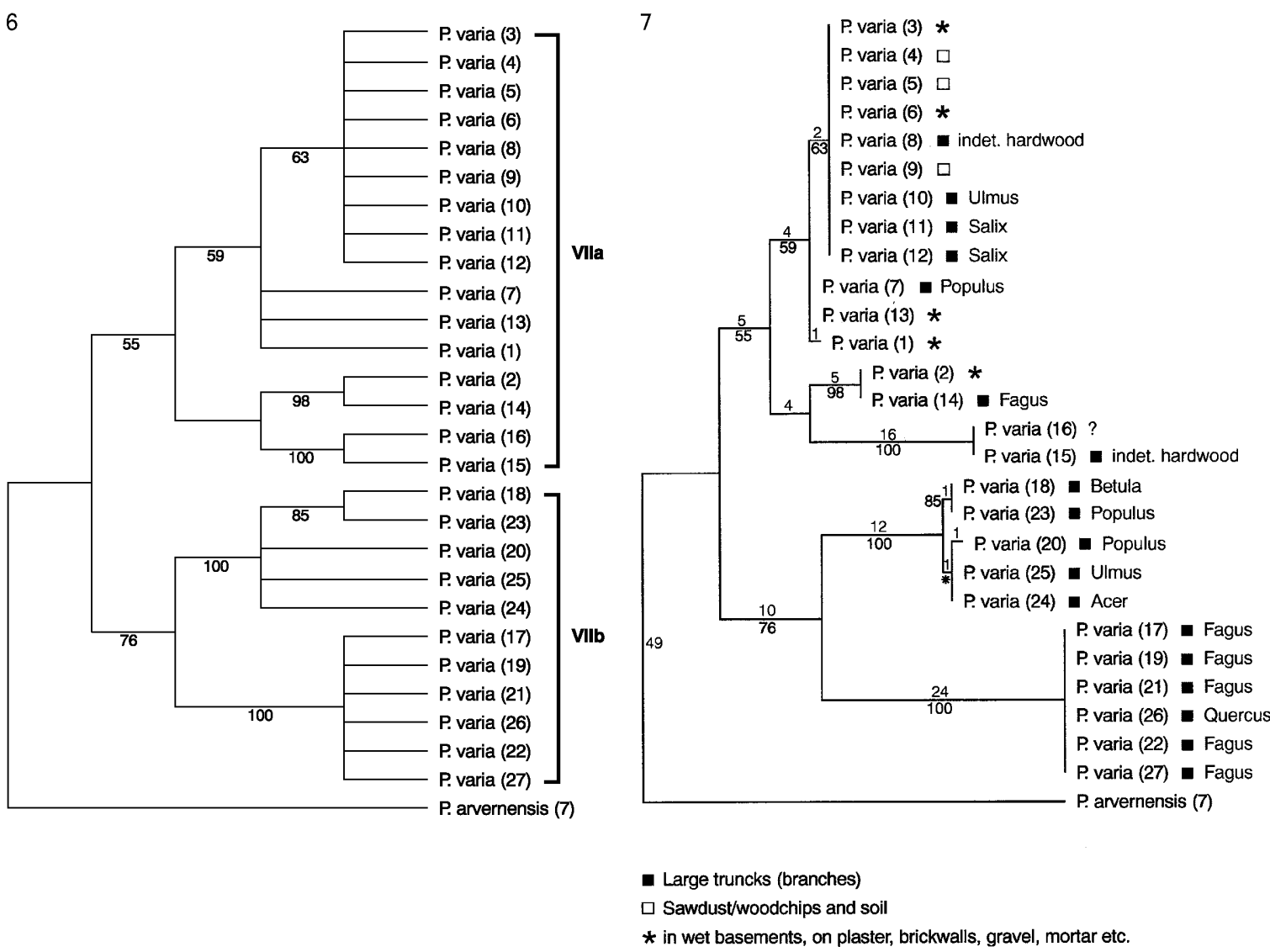

Figs 6-7. Phylogenetic trees generated under indel coding for realigned data of group VII. Terminal taxa are individual specimens. Numbers by branches in black are frequency of occurence in 1000 bootstrap replicates (values $<50 \%$ not shown). Fig. 6. Strict consensus tree of 156 most parsimonious trees. Fig. 7. Phylogram depicting one of 156 most parsimonious trees. Branch lengths are proportional to the number of steps along the branch. Symbols by specimen names indicate the substrate according to the legend.

the thickness of the total exciple. Most probably the thickness of the middle hyphal layer and the exciple overall is affected by edaphic factors. Likewise, the intensity of colour, size and shape of the apothecia may, to a certain degree, be influenced by the substrate and the light conditions, e.g. development of lighter coloured apothecia in dark basements compared to open, outdoor areas, and larger, luxuriant forms on sawdust and highly decayed trunks of Fagus. In agreement with Häffner (1992, 1993) and Kullman (1995), we did not find the presence or absence of a stipe to be taxonomically informative. Both sessile and substipitate specimens (stipe up to $1.5 \mathrm{~cm}$ long $\times 1.3 \mathrm{~cm}$ broad) were represented within the five lineages of group VII. P. cerea, P. micropus, $P$. repanda and $P$. varia have all been characterized by apothecia covered by an outer hyphal layer, with free hyphal tips, appearing whitish, felty upon drying. We found this layer to be very variable in thickness and in some specimens completely absent (in $P$. varia (10) and $P$. varia (26)).

Svrček (1970) noted that $P$. varia differs from $P$. micropus by having a brownish pigmented hyphal layer in the medullary exciple, opposed to P. micropus with a relatively light coloured hyphal layer. Whether this colour variation was a stable character, however, remained unclear to Svrček and has not been confirmed in our study.

Kullman (1995) studied apothecia from one population on plaster over a period of a month and a half. She observed that some of the features considered to be characteristic of the three species $P$. cerea, $P$. micropus and $P$. varia developed over this period, e.g. presence or absence of a stem and the colour of the exciple, and therefore she considered these names to refer to one and the same species.

\section{DISCUSSION}

There are weaknesses in the dataset but these do not appear to be a result of inclusion of ambiguously aligned regions, which could have added noise or been misleading. All phylogenetic resolution receiving even moderate bootstrap support from either of the datasets tested, is compatible with results from all datasets and did not effect conclusions in this study. 

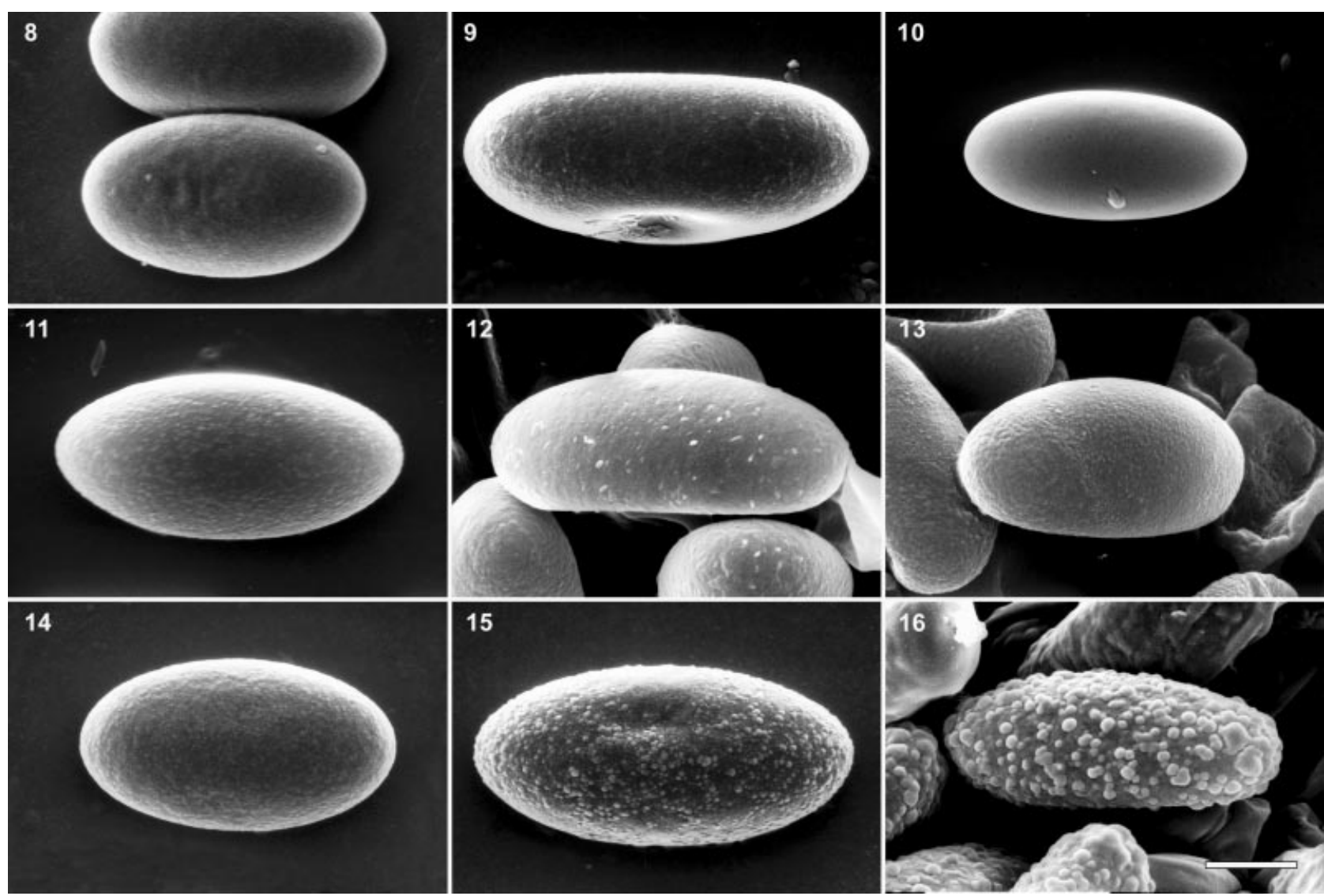

Figs 8-16. Spore ornamentation as seen by SEM for specimens of groups I-III (A). Figs 8-15. Group I and II. Smooth or nearly smooth spores. Fig. 8. Peziza ammophila (1). Fig. 9. P. vesiculosa (4). Fig. 10. P. alcis (2). Fig. 11. P. ampliata (2). Fig. 12. P. fimeti (2). Fig. 13. P. fimeti (7). Fig. 14. P. nivalis (1) Fig. 15. P. sp. a (1). Fig. 16. Group III. P. lohjaënsis (holotype). Irregular, rounded to elongated warts, becoming \pm fused at the poles. Bar $=5 \mu \mathrm{m}$.

\section{Intra- and interspecific ITS variation}

The seven lineages (groups I-VII), distinguished based on ITS sequences, each represent one to several species. Our results suggest that there may be ITS rate heterogeneity within the core group of Peziza. P. varia (group VII) exhibits a high degree of intraspecific variation in the ITS-region compared to, for example, $P$. vesiculosa and $P$. echinispora, which show no variation (Fig. 3). This could be a result of a higher evolutionary rate of ITS within lineage VII and/or partly a result of geographical separation. It appears that the two divergent and highly supported geographical clades within group VIIb have not exchanged genes for a long time (Fig. 7). Some variation in anatomical characters is present within group VII (macromorphology and exciple structure), but these character differences showed no correlation with the groupings obtained by ITS. In general, levels of sequence divergence within group II are low, based on the branch lengths (Fig. 3), which may suggest a lower evolutionary rate of ITS within this lineage or a very recent radiation. In addition, the variation in morphology within group II is low, being primarily in spore size ranges, and in the pigmentation and shape of the paraphyses. The ITS sequence divergence among groups
I-VII is overall quite large, which also can be seen in terms of length variation of the ITS region (Table 2).

\section{Phylogeny within the core group}

\section{Higher level relationships}

The two prominent lineages, A and B (groups II \pm I/III and IV-VII respectively), identified in the phylogenetic analyses, correspond to macromorphologically discrete groups: taxa with small, shallowly cup- to disc-shaped apothecia, generally $<2 \mathrm{~cm}$ (A) and taxa with large, deeply cup-shaped to expanded apothecia (B) (Table 4, Figs 1-3). Exceptions are Peziza lohjaënsis (group III), $P$. ammophila and $P$. vesiculosa (group I), which all produce large apothecia. The position of these taxa is uncertain, resulting in low bootstrap support for lineage A $(<50-63 \%)$, which may include either $P$. lohjaënsis or $P$. ammophila and $P$. vesiculosa (Figs 1-3). Lineage A contains taxa with smooth or nearly smooth spores (Figs 8-15), often with a unilateral, gelatinous coating (not seen in P. ammophila, $P$. domiciliana, $P$. lohjaënsis, $P$. nivalis, $P$. sp. a and $P$. sp. f). A unilateral gelatinous spore coating has not been seen within lineage B. A similar type of mucilaginous substance is present within some coprophilous species of Ascobolus (Ascobolaceae), 

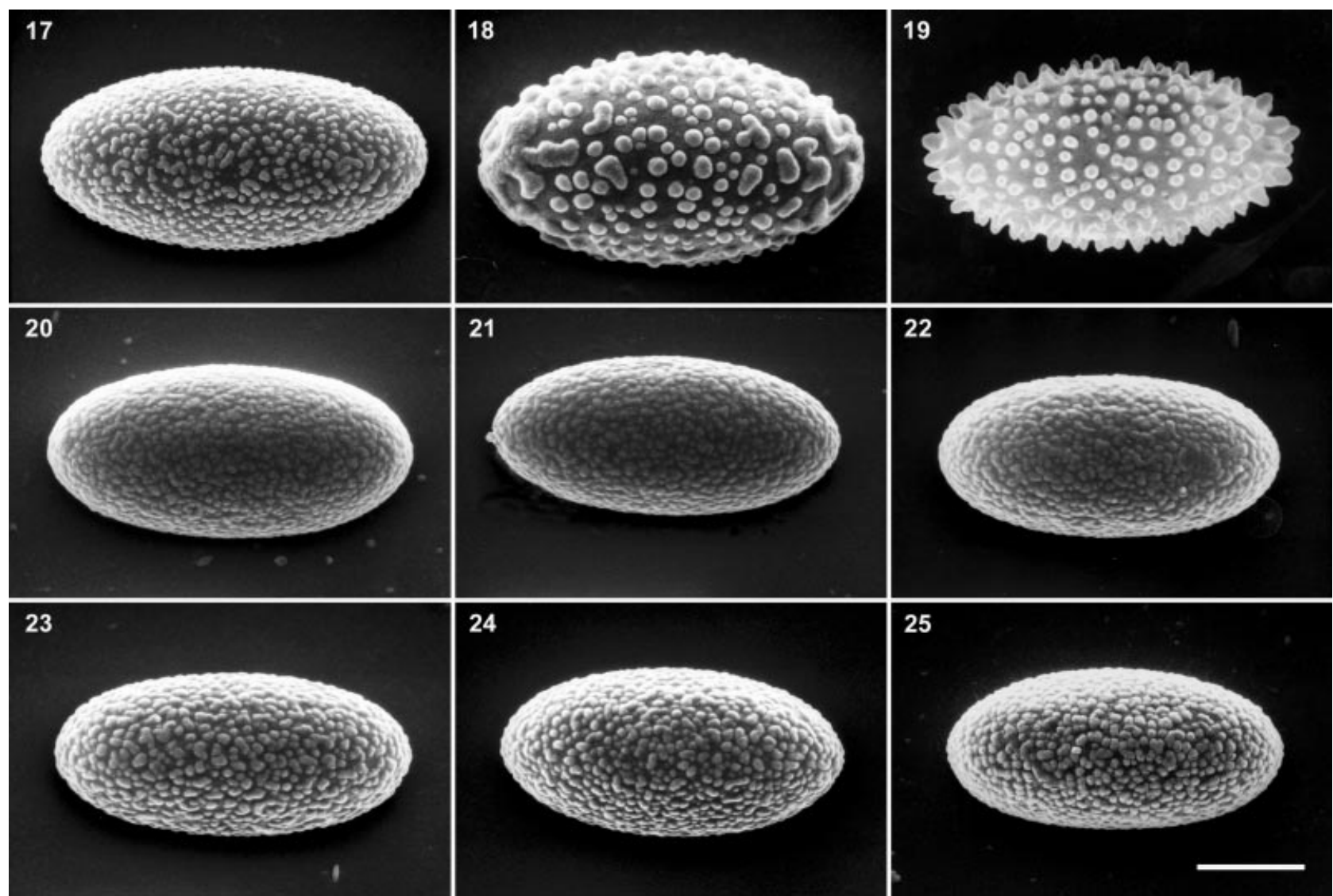

Figs 17-25. Spore ornamentation as seen by SEM for specimens of groups V, VI and VII (B). Figs 17-18. Group V.

Relatively coarse, rounded and elongated warts, irregularly and widely spaced, seen both on the surface and in the outline of the spores. Fig. 17. Peziza arvernensis (7). Fig. 18. P. arvernensis (2). Fig. 19. Group VI. Isolated, regular spines. $P$. echinispora (3). Figs 20-22. Group VIIa. Extremely low, dense warts. Fig. 20. P. varia (1). Fig. 21. P. varia (14). Fig. 22. P. varia (12). Figs 23-25. Group VIIb. Fine, dense warts. Fig. 23. P. varia (20). Fig. 24. P. varia (21). Fig. 25. P. varia (22). Bar $=5 \mu \mathrm{m}$.

the sister group of the Pezizaceae. It is a likely symplesiomorphy for lineage A. P. lohjaënsis differs by having spores with a distinct ornamentation of irregular, rounded to elongated warts, which become \pm fused at the poles (Fig. 16). Species in lineage $B$ have a range of spore surfaces from smooth, $P$. sp. c and $P$. sp. d, to nearly smooth or finely ornamented, $P$. varia (Figs 20-25), to distinctly warted, P. arvernensis (Figs 17-18) or spiny, P. echinispora (Fig. 19).

The overall apothecial excipular structure within lineage B is uniform, with a stratified medullary exciple being composed of 3 layers: (1) of large globose cells with few interwoven hyphae; (2) a dense layer of hyphae running parallel with the outer surface; and (3) a layer identical to the first, of predominantly large globose to angular cells. The outer exciple is not clearly differentiated, but is composed of small globose to angular cells, which typically terminate in short, \pm branching hyphae, forming an often thick tomentose layer. This outer layer turns whitish on drying and sometimes the hyphae aggregate irregularly giving the surface a scurfy appearance. The thickness of the different layers may vary according to substrate and microclimatic conditions. Likewise, the excipular structure is fairly uniform within members of lineage A. In this case the medullary layer is non-stratified being composed of globose cells with few interwoven hyphae; often smaller, globose, \pm brownish pigmented cells form pustules on the outside. Stratified medullary excipules may be present and have been observed in fresh material of P. alcis (2) and P. ampliata (4). The subhymenium and outer exciple are generally of small, globose to angular cells. The placement of $P$. vesiculosa within lineage A (Fig. 2) is not supported by the structure of the exciple. In this taxon there is a stratified medullary exciple as in lineage B. P. ammophila should be studied with respect to this character.

\section{Inter- and intraspecific relationships (I-VII)}

The grouping of Peziza vesiculosa and P. ammophila could be a result of 'long branch attraction' (Felsenstein 1978). Nevertheless, morphological features do not contradict a close relationship between these taxa. Both produce large, deeply cup-shaped apothecia, which initially are almost closed, hollow spheres, with long incurved margins, and the spores are completely smooth and eguttulate. The typical habitats also show similarities. P. ammophila is found with (decaying) grasses (Ammophila) in dunes, and P. vesiculosa is often found 
on manured straw or hay. P. ammophila has been placed in Sarcosphaera (e.g. Seaver 1928, Kotlaba \& Pouzar 1963) based on its initial, partly hypogeous development and the deeply cup-shaped apothecia with margins that split into irregular rays. Likewise, it and another species, P. austrogaster, has been considered to be 'unique' within Peziza, and a subgenus Asterosphaera was established with $P$. ammophila as the type species by Pouzar (1972). Most authors have considered the similarities in macromorphological development between Sarcosphaera and P. ammophila to be a result of convergent or parallel evolution. This is congruent with our results based on LSU sequences (Hansen et al. 2001) and ITS rDNA sequences, which support $P$. ammophila in Peziza s. str. Furthermore, the presence of a distinctly amyloid ascus ring zone and an Oedocephalum anamorph (Paden 1973) justify its placement in the group. Sarcosphaera represents a separate lineage (Hansen et al. 2001).

All taxa with small apothecia (generally $<2 \mathrm{~cm}$ ) sampled within the core group of Peziza form a monophyletic group (group II). This includes $P$. fimeti (including $P$. granulosa sensu Boudier; see above), $P$. alcis, $P$. nivalis, $P$. domiciliana, $P$. ampliata and a number of putative, undetermined species. The named species figure in most keys and other literature on Peziza (e.g. Le Gal 1941, Donadini 1977, 1979, Hohmeyer 1986, Dissing 2000, Spooner 2001). Based on analyses of ITS, group II members appear to be very closely related, assuming that the ITS rDNA phylogeny is congruent with the population phylogeny, and they may not all represent separate evolving lineages. The uniformity within this group is reflected in the structure of the apothecia, where only very subtle differences are seen. Species within group II have been distinguished primarily by hymenial colours; presence or absence of a crenulate margin; spore sizes and shape; content of the paraphyses; and, to a large extent, the substrate. They produce apothecia in a wide range of habitats but, based on the ITS phylogeny, most are not confined to specific habitats (Fig. 5). P. fimeti fruits not only on cow and horse dung but also on other types of dung, sawdust-mixed soil, bare soil and burnt ground. Likewise, analyses of ITS did not identify other lineages of specimens occurring on bare ground (clay, rich soil and chalk) vs wood, or on burnt vs unburnt ground (Fig. 5). Nevertheless, P. alcis appears to be a welldefined lineage confined to elk dung and $P$. nivalis to dead grasses in snow beds (Figs 4-5).

Group III contains $P$. lohjaënsis, which forms either a separate lineage as a sister group to the rest of the core group of Peziza (Fig. 2) or a weakly supported monophyletic group with group II (Figs 1, 3). Harmaja (1986) suggested that $P$. lohjaënsis was related to $P$. phaeotheca, a snowbank fungus (treated as a synonym of $P$. nivalis by Pfister (1992), a group II member), which like $P$. lohjaënsis possesses brownish ascus walls and occurs in spring. On the other hand, other features, such as the size of the apothecia and spore orna- mentation (Figs 16-18), point to a closer relationship with $P$. arvernensis (group V). Further morphological and molecular studies of additional specimens of $P$. lohjaënsis are needed.

Group IV represents an as yet unidentified species, $P$. sp. c, which constitutes a well-separated lineage. The position of $P$. sp. c within lineage B is uncertain, being unresolved in the strict consensus tree of the inclusive dataset (Fig. 1). In the strict consensus tree of the exclusive dataset it forms a separate lineage as a sister group to $P$. echinispora, $P$. sp. d, and $P$. varia (groups VI-VII) (Fig. 2). The two specimens of $P$. sp. c were found in the same habitat as some specimens of $P$. varia, that is, sawdust and soil. Morphologically $P$. sp. $\mathrm{c}$ is primarily distinguished within lineage $\mathrm{B}$ by the larger, completely smooth spores (Table 4).

Group V contain nine collections of $P$. arvernensis, which are highly supported as monophyletic in the inclusive dataset analysis ( $98 \%$ bootstrap, Fig. 1) but only weakly supported in the exclusive dataset analysis (58\% bootstrap, Fig. 2). Two geographical subclades, $\mathrm{Va}$ and $\mathrm{Vb}$, were highly supported in both analyses; no morphological differences were observed between the subclades. The position of $P$. arvernensis within lineage $\mathrm{B}$ is unresolved in the inclusive dataset (Fig. 1). In the exclusive dataset it is a sister group to the rest of lineage B (Fig. 2). Based on ITS sequences, spore ornamentation, and habitat (Figs 17-18), P. arvernensis appears to be a distinct species.

Group VI includes two distinct species, P. echinispora and $P$. sp. d. No obvious morphological characters support this particular grouping within lineage B, which could, like group I, be explained by 'long branch attraction' (Felsenstein 1978). Rather, based on the spore characters (size and lack of ornamentation) and the substrate, a close relationship between $P$. sp. $\mathrm{d}$ and $P$. sp. c would be expected. The spore ornamentation in P. echinispora, isolated, regular spines, up to $1 \mu \mathrm{m}$ high, is unique within the ingroup. The excipular structure of P. echinispora is similar to that found in other lineage B members.

Within group VII we recognize a single lineage, $P$. varia, based on ITS, morphological criteria studied, and substrate. It could be argued that the two lineages, VIIa and VIIb, recovered in all MPT's of the exclusive dataset and the restricted group VII dataset (Figs 2, 6-7) and supported by small differences in spore markings, could represent two species (see notes on $P$. varia under 'Taxonomic implications' above). Nevertheless, the strongly supported subclades within group VII seem only to represent different populations of $P$. varia. Characters such as moniliform $v s$ filiform paraphyses, presence or absence of a stipe, colour variation in the apothecia, stratified or non-stratified medullary exciples (or thickness of the exciple layers) and cell types in the outermost layer of the exciple, previously used to delimit species within the ' $P$. varia complex', were not correlated with the subgroups identified by analyses of ITS sequences and appeared to 
be plastic. In addition, substrate has been emphasized in the taxonomy of the ' $P$. varia complex' but our results indicate that populations on a diverse array of substrates, may be closely related (Fig. 7). On the other hand, we may not understand the substrate preferences and the biology of these fungi well enough for meaningful comparisons.

\section{CONCLUSIONS}

Overall this study implies that morphological features previously used to distinguish many of the taxa within the core group of Peziza are plastic. The use of substrate as a primary character for species recognition has, in addition, been misleading within some lineages. Spore ornamentation and size, and paraphyses pigmentation and shape proved, for the most part, to be useful at the specific level. Apothecia size and shape, overall exciple structure, and to some degree spore surface relief, seem to be phylogenetically informative for higher level relationships within the group. Two main clades, including seven independent lineages were identified. Within these we currently recognize thirteen species, along with a number of entities of yet uncertain status. Our critical evaluation of the taxa involved, their delimitation and the designation of types as required, provides a stable framework for future investigations of these fungi.

To understand phylogenetic relationships and define species boundaries within group II, analyses of other genes may prove useful (Taylor et al. 2000). Candidate genes would include the intergenic spacer IGS rDNA (Anderson \& Stasovski 1992), part of RPB2 (Liu, Whelen \& Hall 1999) or translation elongation factor (EF-1a) gene (O'Donnell 2000). Likewise, phylogenetic studies of multiple genes within group VII, would be valuable in a further exploration of the species limits and the ITS subclades identified in the present study. Morphological features of anamorphs rather than of teleomorphs have proven phylogenetically informative at the species level in some groups of fungi (Takamatsu, Hirata \& Sato 1998, Réblová \& Winka 2000). Although only Oedocephalum anamorphs have been reported within the core group of Peziza, these exhibit considerable variation. Culture characteristics and anamorph features could possibly contribute new and phylogenetically valuable information in this morphologically conserved group.

\section{ACKNOWLEDGEMENTS}

We are grateful to Sara Landvik (Novozymes A/S, Copenhagen), for discussions on alignment and phylogenetic analyses, and for doing the molecular work on 15 of the specimens, to Henning Knudsen for valuable advice and help on taxonomic and nomenclatural aspects, and to David S. Hibbett for helpful comments on the manuscript. We thank the curators of C, FH, G, H, K, L, PC, PRM, TUR and TURA for arranging loans of material, and Betty Klug-Andersen, Henry Dissing, Steen A. Elborne, Kitty Griffith, Sven-Åke Hanson, Jakob Heilmann-Clausen, Henning Knudsen, Roy Kristiansen, Christian
Lange, Jens H. Petersen, Trond Schumacher, Brian M. Spooner, Anne Storgaard, Jukka Vauras, and Wulfard Winterhoff for providing specimens, Nancy Weber for sharing her specimens with macro- and microscopical notes from fresh material, Charlotte Hansen for some of the DNA sequencing, Kim B. Petersen for sequence cloning, Else Meyer Andersen for preparing the SEM photographs, and Leif Bolding for valuable help with the graphics. This research was supported by a grant from the Faculty of Science, University of Copenhagen to K.H. and by an NSF grant (DEB9521944) to D.H.P.

\section{REFERENCES}

Anderson, J. B. \& Stasovski, E. (1992) Molecular phylogeny of northern hemisphere species of Armillaria. Mycologia 84: 505-516.

Berthet, P. (1964a) Essai biotaxinomique sur les Discomycètes. Thèses, Université de Lyon.

Berthet, P. (1964b) Formes conidiennes de divers Discomycètes. Bulletin de la Société Mycologique de France 80: 125-149.

Berthet, P. (1970) Les ornamentations sporales meconnues de cinq especes de Discomycetes opercules. Extrait du Bulletin Menusel de la Société Linnéenne de Lyon 9: 289-292.

Boudier, J. L. É. (1885) Nouvelle classification naturelle des Discomycètes charnus connus gènèralement sous le nom de Pézizes. Bulletin de la Société Mycologique de France 1: 91-120.

Boudier, J. L. É. (1905-10) Icones Mycologicae. 4 vols. Paul Klincksieck, Paris.

Boudier, J. L. É. (1907) Histoire et classification des Discomycètes d'Europe. Paul Klincksieck, Paris.

Breitenbach, J. \& Kränzlin, F. (eds) (1984) Pilze der Schweiz. Vol. 1. Ascomyceten. Verlag Mykologia, Luzern.

Bresadola, G. (1933) Iconographia mycologica. Vol. 25. Societa botanica italiana, Milan.

Cacialli, G., Caroti, V. \& Doveri, F. (1995) Funghi fimicoli e rari o interessanti del litorale toscano. Schede de micologia 1: 1-615.

Cooke, M. C. (1879) Mycographia, seu Icones Fungorum. Vol. 1. Discomycetes. Williams \& Norgate, London.

Dennis, R. W. G. (1981) British Ascomycetes. 4th edn. J. Cramer, Vaduz.

Dissing, H. (2000) Pezizales. In Nordic Macromycetes (L. Hansen \& H. Knudsen, eds) : 1: 55-128. Nordsvamp, Copenhagen.

Donadini, J. C. (1977) Le genre Peziza L. per Saint-Amans (I). Bulletin de la Société Linnéenne de Provence 30: 37-92.

Donadini, J. C. (1978) Le genre Peziza L. per Saint-Amans (II). Les Pezizes de Haute-Provence et de Dauphiné-Savoie. Bulletin de la Société Mycologique de France 31: 9-36.

Donadini, J. C. (1979) Le genre Peziza Linné per Saint-Amans (lére Partie). Documents mycologiques 9: 1-42.

Donadini, J. C. (1980a) Le genre Peziza. IV. Les Pezizes nivales. Bulletin de la Société Mycologique de France 96: 247-248.

Donadini, J. C. (1980b) Le genre Peziza (suite). Fortoulisme. Critères taxinomiques ches les Discomycètes operculés. Documents mycologiques 11: 27-30.

Felsenstein, J. (1978) Cases in which parsimony or compatibility methods will be positively misleading. Systematic Zoology 27: 401-410.

Gamundí, I. J. (1975) Fungi, Ascomycetes, Pezizales. In Flora Criptogámica de Tierra del Fuego (S. A. Guarrera, I. Gamundí de Amos \& D. Rabinovich de Halperin, eds) 10(3): 7-184.

Ginns, J. (1980) Peziza varia. Fungi Canadenses 169: [1-2]

Hansen, K., Pfister, D. H. \& Hibbett, D. S. (1999) Phylogenetic relationships among species of Phillipsia inferred from molecular and morphological data. Mycologia 91 : 299-314.

Hansen, K., Læssøe, T. \& Pfister, D. H. (2001) Phylogenetics of the Pezizaceae, with an emphasis on Peziza. Mycologia 93: 958-990.

Häffner, J. (1992) Rezente Ascomycetenfunde-XI, Sterigmate formen in der gattung Peziza (1. Teil). Persoonia 14: 597-602.

Häffner, J. (1993) Rezente Ascomycetenfunde-XI, Sterigmate formen in der gattung Peziza (2. Teil). Persoonia 15: 179-185.

Harmaja, H. (1986) Studies on the Pezizales. Karstenia 26: 41-48. 
Hawksworth, D. L., Kirk, P. M., Sutton, B. C. \& Pegler, D. N. (1995) Ainsworth \& Bisby's Dictionary of the Fungi. 8th edn. CAB International, Wallingford.

Hibbett, D. S., Fukumasa-Nakai, Y., Tsuneda, S. \& Donoghue, M. J. (1995) Phylogenetic diversity in shiitake inferred from nuclear ribosomal DNA sequences. Mycologia 87: 618-638.

Hohmeyer, H. (1986) Ein Schlüssel zu den europäischen Arten der Gattung Peziza L. Zeitschrift für Mykologie 52: 161-188.

Karsten, P. A. (1869) Monographia Pezizarum fennicarum. Notiser ur Sällskapets pro Fauna et Flora Fennica Förhandlingar, n.s. 7 : 99-206.

Karsten, P. A. (1871) Mycologia Fennica Vol. 1. Discomycetes. Bidrag till kännedom af Finlands Natur och Folk 19: 1-263.

Korf, R. P. (1973) Discomycetes and Tuberales. In The Fungi: an advanced treatise (G. C. Ainsworth, F. K. Sparrow \& A. S. Sussman, eds) 4 A: 249-319. Academic Press, New York.

Kotlaba, F. \& Pouzar, Z. (1963) Two rare arenicolous fungi in Czechoslovakia: Psathyrella ammophila (Dur. et Lév.) P. D. Orton and Sarcosphaera ammophila (Dur. et Mont.) Moesz. Česká Mykologie 17: 71-76.

Kullman, B. (1995) Peziza varia - a moisture loving guest in our homes. [abstract] Estonian Nature 8: 219.

Le Gal, M. (1941) Les Aleuria et les Galactinia. Revue de Mycologie, Supplément 6: 56-82.

Liu, Y. J., Whelen, S. \& Hall, B. D. (1999) Phylogenetic relationships among ascomycetes: evidence from an RNA polymerase II subunit. Molecular Biology and Evolution 16: 1799-1808.

Maas Geesteranus, R. A. (1967) De Fungi van Nederland II. Pezizales-deel I. - Wetenschappelijke Mededelingen van de Koninklijke Nederlandse Natuurhistorische Vereniging 69: 1-84.

Maddison, D. R., Ruvolo, M. \& Swofford, D. L. (1992) Geographic origins of human mitochondrial DNA: phylogenetic evidence from control region sequences. Systematic Biology 41: 111-124.

Moser, M. (1963) Ascomyceten. In Kleine Kryptogamenflora (H. Gams, ed.) 2a: 1-147. Gustav Fischer Verlag, Stuttgart.

Norman, J. E. \& Egger, K. N. (1996) Phylogeny of the genus Plicaria and its relationship to Peziza inferred from ribosomal DNA sequence analysis. Mycologia 88: 986-995.

Norman, J. E. \& Egger, K. N. (1999) Molecular phylogenetic analysis of Peziza and related genera. Mycologia 91: 820-829.

O'Donnell, K. (2000) Molecular phylogeny of the Nectria haematococca-Fusarium solani species complex. Mycologia 92: 919-938.

Olmstead, R. G., Bremer, B., Scott, K. M. \& Palmer, J. D. (1993) A molecular systematic analysis of the Asteridae sensu lato based on $r b c \mathrm{~L}$ sequences. Annals of the Missouri Botanical Garden 80: 700-722.

Paden, J. W. (1973) The conidial state of Peziza ammophila. Canadian Journal of Botany 51: 2251-2252.

Pouzar, Z. (1972) Sarcosphaera crassa (Santi ex Steud.) Pouz., the correct name for Sarcosphaera coronaria (Jacq. ex M. C. Cooke) J. Schroet. (Pezizaceae). Česká Mykologie 26: 32-36.
Pfister, D. H. (1992) A collection of Peziza nivalis from California with comments on the nomenclature of the snow bank Pezizas. Mycotaxon 43: 171-175.

Rambaut, A. (1996) Se-Al. Sequence Alignment Editor. Version 1.0 alpha 1. University of Oxford, Oxford. [http://evolve. zoo.ox.ac.uk/Se-Al/Se-Al.html.].

Réblová, M. \& Winka, K. (2000) Phylogeny of Chaetosphaeria and its anamorphs based on morphological and molecular data. Mycologia 92: 939-954.

Rifai, M. A. (1968) The Australasian Pezizales in the herbarium of the Royal Botanic Gardens, Kew. Verhandelingen der Koninklijke Nederlandse Akademie van Wetenschappen, Afd Natuurkunde II, 57: 1-295.

Romagnesi, H. (1978) Les espèces du genre Peziza St-Am. (= Aleuria sensu Boud. et Galactinia Cke sensu Boud.). Bulletin Trimestriel de la Féderation Mycologique Dauphiné-Savoie 18: 19-23.

Ryman, S. \& Holmåsen, I. (1984) Svampar. 3rd edn. Interpublishing $\mathrm{AB}$, Stockholm.

Seaver, F. J. (1928) The North American cup-fungi (operculates). Hafner Publishing, New York.

Spooner, B. [M.] (2001) The larger cup fungi in Britain - part 3. The genera Peziza and Plicaria. Field Mycology 2: 51-59.

Spooner, B. M. \& Yao, Y.-J. (1995) Notes on British taxa referred to Aleuria. Mycological Research 99: 1515-1518.

Stafleu, F. A. \& Cowan, R. S. (1976) Taxonomic Literature. 2nd edn. Vol. 1 [Regnum Vegetabile Vol. 94] Bohn Scheltema \& Holkema, Utrecht.

Svrček, M. (1970) Über einige arten der Discomycetengattung Peziza [Dill.] L. ex St-Amans. Ceská Mykologie 24: 57-76.

Svrček, M. \& Kubicka, J. (1961) Some operculate Discomycetes from the vicinity of the pond 'Dvoriste' in Southern Bohemia. Česká Mykologie 15: 61-77.

Swofford, D. L. (1998) PAUP*: phylogenetic analysis using parsimony ( ${ }^{*}$ and other methods). Version 4. Sinauer Associates, Sunderland, MA.

Takamatsu, S., Hirata, T. \& Sato, Y. (1998) Phylogenetic analysis and predicted secondary structures of the rDNA internal transcribed spacers of the powdery mildew fungi (Erysiphaceae). Mycoscience 39: 441-453.

Taylor, J. W., Jacobsen, D. J., Kroken, S., Kasuga, T., Geiser, D. M., Hibbett, D. S. \& Fisher, M. C. (2000) Phylogenetic species recognition and species concepts in fungi. Fungal Genetics and Biology 31: 21-32.

Webster, J., Rifai, M. A. \& Samy El-Abyad, M. (1964) Culture observations on some discomycetes from burnt ground. Transactions of the British Mycological Society 47: 445-454.

White, T. J., Bruns, T. D., Lee, S. \& Taylor, J. W. (1990) Amplification and direct sequencing of fungal ribosomal RNA genes for phylogenetics. In PCR Protocols (M. A. Innis, D. H. Gelfand, J. J. Sninsky \& T. White, eds): 315-322. Academic Press, San Diego.

Corresponding Editor: D. L. Hawksworth 